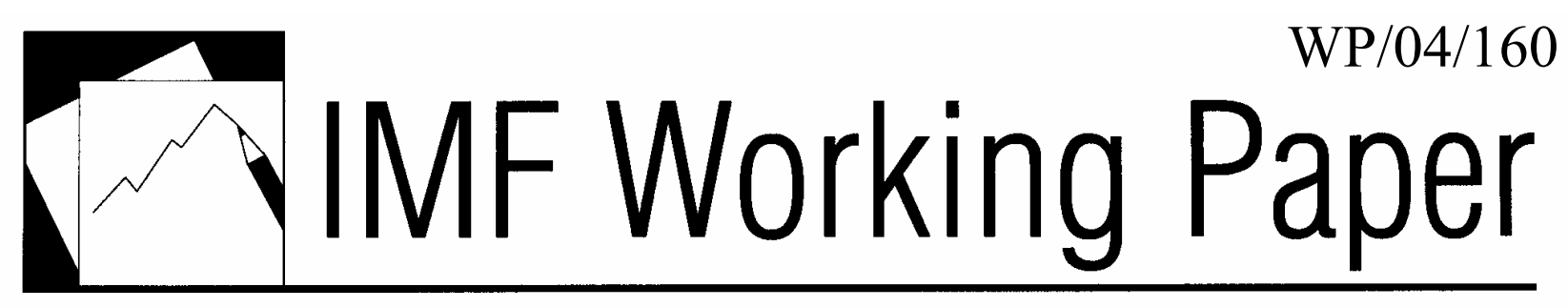

\title{
External Debt Sustainability in HIPC Completion Point Countries
}

\author{
Yan Sun
}




\title{
IMF Working Paper
}

Finance Department

\section{External Debt Sustainability in HIPC Completion Point Countries}

\author{
Prepared by Yan Sun ${ }^{1}$
}

Authorized for distribution by Jianhai Lin

September 2004

\begin{abstract}
This Working Paper should not be reported as representing the views of the IMF. The views expressed in this Working Paper are those of the author(s) and do not necessarily represent those of the IMF or IMF policy. Working Papers describe research in progress by the author(s) and are published to elicit comments and to further debate.

This paper examines a number of structural factors affecting the external debt sustainability of HIPC completion point countries. It shows that (i) while comparing favorably with other low-income countries, the policy and institutional frameworks of completion point countries in general are still relatively weak, and their debt management practices remain inferior to international standards; and (ii) their export base remains narrow and fiscal revenue mobilization lags behind, even compared with many other low-income countries. Achieving and maintaining long-term debt sustainability in completion point countries will require continued structural reforms, timely donor support, and close monitoring of new borrowing in support of sound macroeconomic policies.

JEL Classification Numbers: F34, F35, O19

Keywords: External debt sustainability, HIPC

Author's E-Mail Address: Ysun2@imf.org

\footnotetext{
${ }^{1}$ The author would like to thank Jianhai Lin for initiating and supporting this project, and Dan Nyberg, Nathan Porter, Andrew Tweedie, Nancy Wagner, and participants at the seminar in the IMF Finance Department for comments and suggestions. The author would also like to thank Yan Sun-Wang for help with charts and tables. The author is responsible for errors.
} 


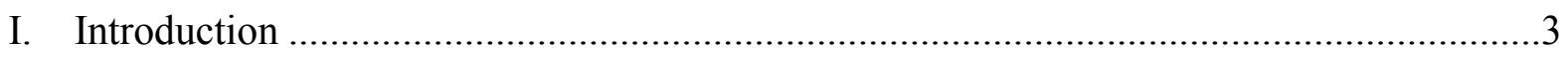

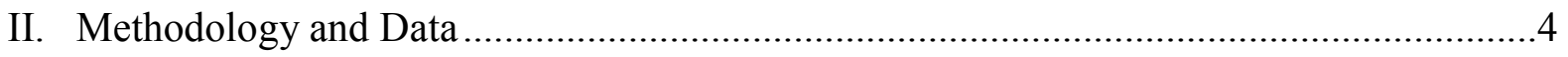

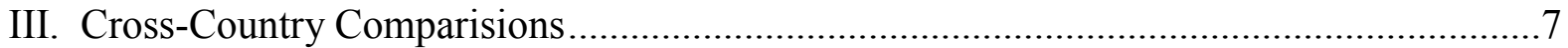

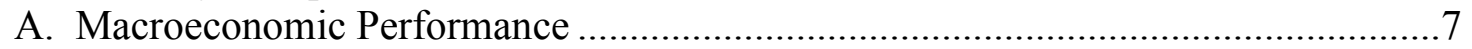

B. Policy and Institutional Frameworks................................................................ 10

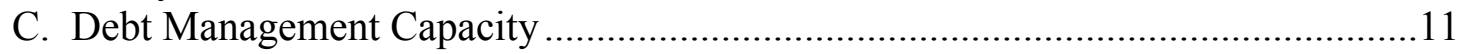

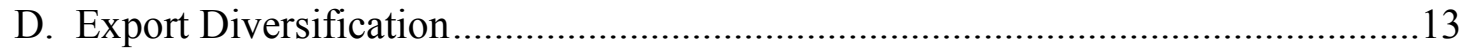

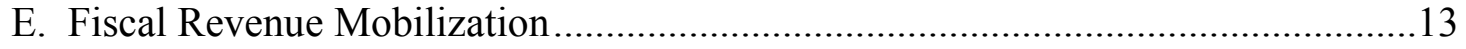

IV. Concluding Remarks ..................................................................................... 14

Figures

1. Macroeconomic Stability and Growth in Low-Income Countries.................................8

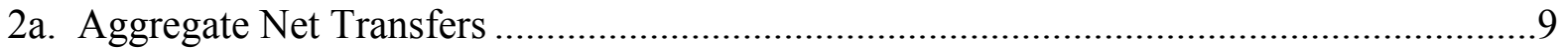

2b. Share of Aggregate Net Transfers............................................................................. 9

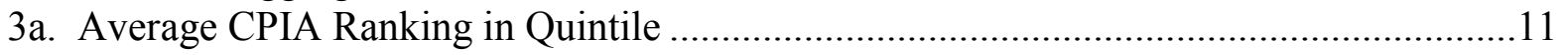

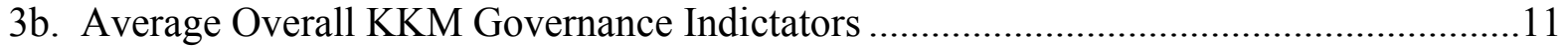

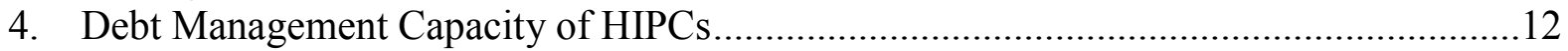

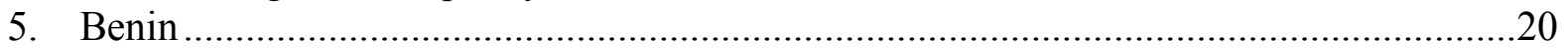

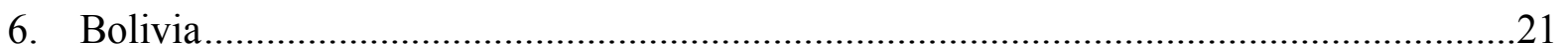

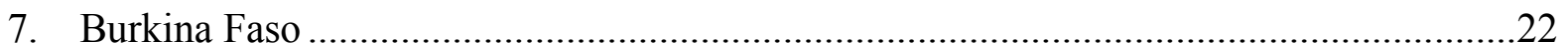

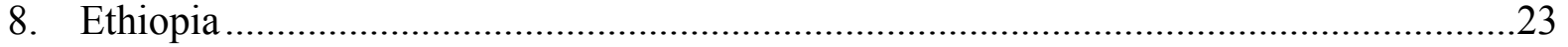

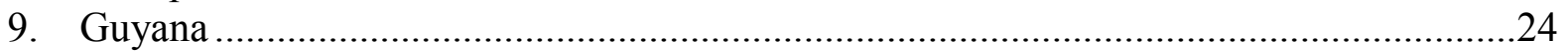

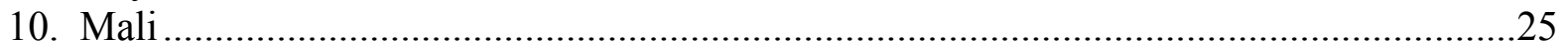

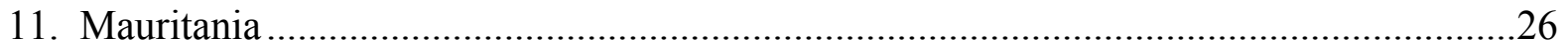

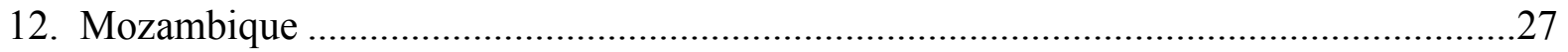

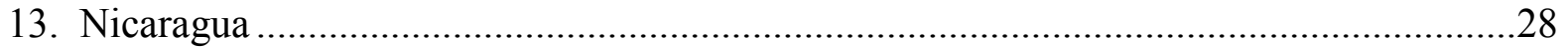

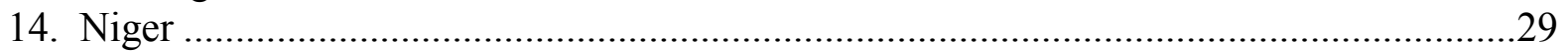

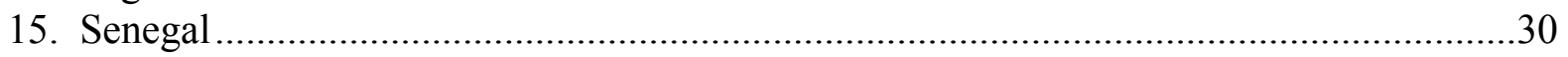

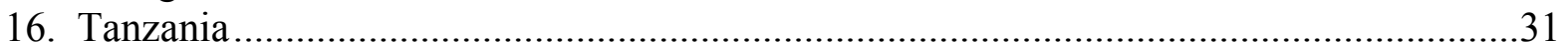

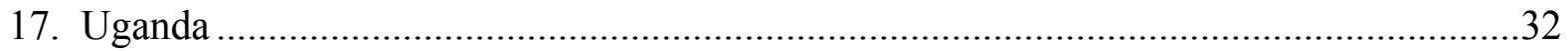

Tables

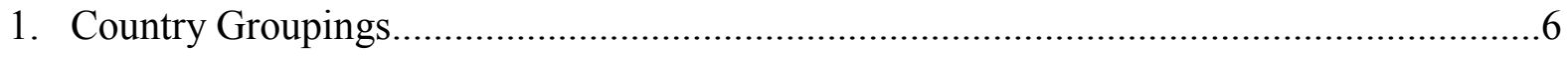

2. CPIA Index of Completion Point Countries ......................................................... 16

3. Group Average of KKM Governance Indicators....................................................... 17

4. Export Diversification and Revenue Mobilization in Completion Point Countries..........18

5. Central Government Revenue-to-GDP Ratios in Completion Point Countries During $1992-2002$

References 


\section{Introduction}

Reflecting concerns about the negative impact of excessive debt burdens on growth, the Heavily Indebted Poor Countries (HIPC) Initiative was launched in 1996 and was then "enhanced" in 1999 to provide broader, faster, and deeper debt relief to some of the world's poorest and most heavily indebted countries. Under the Enhanced HIPC Initiative, 38 countries are currently eligible for debt relief. As of end-June 2004, 13 countries have reached the completion point, 14 countries have reached the decision point but not yet the completion point, and another 11 countries have not yet reached the decision point. $^{2}$

While the external debt stocks of HIPC completion point countries have been reduced substantially, exiting from the HIPC initiative does not, in and of itself, guarantee long-term external debt sustainability. In fact, if structural weaknesses in their economies continue to prevail and macroeconomic management does not improve, completion point countries might well slip back into the debt trap again. For instance, the importance of export diversification has been underscored by the deterioration of debt indicators in many HIPCs during the 2001/2002 declines in commodity prices and the global economic slowdown.

Recognizing the importance of structural reforms in securing and maintaining debt sustainability, this paper examines several factors - policy and institutional frameworks, debt management capacity, export diversification, and fiscal revenue collection - in completion point countries to broadly assess their outlook for debt sustainability. The idea is that achievement and maintenance of debt sustainability will be elusive if a country is stuck with poor policy and institutional frameworks, inadequate debt management, a narrow export base, and weak fiscal revenue mobilization. Based on available data, the paper looks at indicators in the above four areas in completion point countries as a whole and compares them with those in other lowincome countries and with international standards. The paper also examines each completion point country individually to identify relatively strong and weak performers.

A 2002 IMF Board paper examined the Enhanced HIPC Initiative and its impact on the achievement of long-term debt sustainability. ${ }^{3}$ It looked at a range of quantitative debt indicators, including the widely-used net present value (NPV) of debt-to-exports ratio and debt service-to-exports ratio, based on medium-term projections of economic variables and new borrowing. This paper instead looks at indicators of four structural factors that could

\footnotetext{
2 As of end-June 2004, the 13 completion point countries are Benin, Bolivia, Burkina Faso, Ethiopia, Guyana, Mali, Mauritania, Mozambique, Nicaragua, Niger, Senegal, Tanzania, and Uganda. The 14 interim countries are Cameroon, Chad, Democratic Republic of Congo, The Gambia, Ghana, Guinea, Guinea Bissau, Honduras, Madagascar, Malawi, Rwanda, São Tomé and Príncipe, Sierra Leone, and Zambia. HIPCs that have not reached the decision point include Burundi, Central African Republic, Comoros, Republic of Congo, Côte d'Ivoire, Lao PDR, Liberia, Myanmar, Somalia, Sudan, and Togo.

${ }^{3}$ The Enhanced HIPC Initiative and the Achievement of Long-Term External Debt Sustainability (http://www.imf.org/external/np/hipc/2002/lteds/041502.htm).
} 
fundamentally affect a HIPC's underlying prospects for achieving and maintaining debt sustainability. Absent these critical factors, sustainability could prove elusive.

The rest of the paper is organized as follows. Section II sets out the methodology and data. Results of cross-country comparisons and country case studies are presented in Section III. Section IV provides conclusions.

\section{Methodology and Data}

Debt relief itself does not necessarily bring about long-term debt sustainability. While donors and creditors can play an important role, the responsibility of achieving long-term debt sustainability ultimately lies with low-income countries themselves. Available evidence indicates that sound policy and institutional frameworks, adequate debt management capacity, and a diversified export base are important for supporting long-term debt sustainability. One such study by Brooks et al (1998) looked at the external debt histories of ten low-income countries and found that exogenous shocks, a lack of sustained reforms, inadequate debt management, and overly optimistic economic projections were the main factors behind the buildup of external debts. In particular, they highlighted the critical importance of sound policies, adequate debt management capacity, and a diversified export base in achieving and maintaining debt sustainability.

HIPCs' outlook for maintaining external debt sustainability will also be affected by their ability to mobilize domestic revenues. Specifically, weak fiscal revenue mobilization can unduly constrain the ability of countries to meet expenditure priorities and cope with shocks, and leave them excessively dependent on external aid flows and borrowing, which can be volatile and expensive. The importance of fiscal revenue mobilization is recognized in the design of the HIPC Initiative framework. As a matter of fact, if a country's NPV of debt-to-exports ratio is below the HIPC threshold of 150 percent, it may still qualify for HIPC assistance under the socalled fiscal window of the HIPC Initiative - a NPV of debt-to-government revenue ratio of more than 250 percent.

The important impact of a country's structural characteristics on its ability to carry debt has been recognized by the Fund in developing a forward-looking framework to establish debt sustainability beyond the HIPC Initiative. ${ }^{4}$ In particular, this framework notes that: (i) weak policies and institutions, and generally low implementation capacity in low-income countries put the uses and management of resources at risk; and (ii) narrow and highly volatile production and export bases in low-income countries make them particularly vulnerable to shocks that can significantly worse their debt dynamics. Therefore, the debt sustainability assessment approach adopted by the framework incorporates an explicit evaluation of a country's policies and institutions, and stress tests to capture its vulnerability to shocks. ${ }^{5}$

\footnotetext{
${ }^{4}$ Debt-Sustainability in Low-Income Countries-Proposal for an Operational Framework and Policy Implications (http://www.imf.org/external/np/pdr/sustain/2004/020304.pdf).

${ }^{5}$ Both the Bank and Fund empirical analyses found that policies and shocks had strong predictive power for predicting episodes of debt distress.
} 
In light of the above, this paper examines how the current group of completion point countries stand in terms of available structural indicators on policy and institutional frameworks, debt management capacity, export diversification, and fiscal revenue mobilization, as a means of assessing their prospects for achieving and maintaining long-term external debt sustainability. Ideally, one could look at how these structural indicators have changed over time, particularly from the pre-HIPC to post-HIPC period. However, the fact that time series of structural indicators do not exist and that many countries only reached the completion point recently precludes such analysis. Instead, this paper relies on cross-country comparisons to get a sense of where these completion point countries stand at this stage. Specifically, to identify areas of relative strength and weakness, it compares completion point countries' structural indicators with those in other low-income countries and with international standards. Recognizing the diversity among completion point countries, the paper also looks at countries individually to identify relatively strong and weak performers.

Other low-income countries cover the rest of HIPCs ("HIPC rest" or "other HIPCs" hereafter) -including HIPC countries that have reached the decision point, but not yet the completion point, and those that have not reached the decision point - as well as non-HIPC PRGF countries ("PRGF countries" hereafter). ${ }^{6}$ Countries for all three groups are listed in Table 1 . The comparisons between completion point countries and PRGF countries are of particular interest. If completion point countries do not compare favorably even with non-HIPC PRGF countries, they would very likely have a long way to go to achieve long-term external debt sustainability, despite the fact that they have exited from the HIPC Initiative. ${ }^{7}$

Available data on structural indicators are limited, both in terms of country coverage and time span. This paper uses the World Bank's Country Policy and Institutional Assessment (CPIA) index to measure policy and institutional frameworks, supplemented with the governance indicators compiled by Kaufmann, Kraay, and Mastruzzi (KKM). ${ }^{8}$ A country's debt management capacity is quantified by data from Debt Relief International (DRI). The share of commodity exports in total exports is calculated to measure a country's degree of export diversification. The larger the share, the less diversified a country's exports and the more vulnerable it is to commodity price shocks. Fiscal revenue mobilization is measured by the central government revenue-to-GDP ratio (excluding grants).

\footnotetext{
${ }^{6}$ To strengthen comparability between HIPCs and non-HIPC PRGF countries, PRGF countries in this paper include only PRGF-eligible countries that have had PRGF arrangements as of endJune 2004. There are twenty-four countries in this category.

${ }^{7}$ For a comparison of debt indicators between HIPCs and other developing countries, see Box 1 in the September 2004 HIPC implementation report (Enhanced HIPC Initiative-Status of Implementation).

${ }^{8}$ Kaufmann, Daniel, Aart Kraay, and Massimo Mastruzzi, 2003, “Governance Matters III: Governance Indicators for 1996-2002," World Bank Policy Research Working Paper 3106.
} 
Table 1. Country Groupings

(Status as of End-June 2004)

\begin{tabular}{ll}
\hline HIPC Completion Point Countries (13) & Benin, Bolivia, Burkina Faso, Ethiopia, Guyana, Mali, \\
& Mauritania, Mozambique, Nicaragua, Niger, Senegal, \\
& Tanzania, and Uganda. \\
& Burundi, Cameroon, Central African Republic, Chad, \\
Other HIPCs (25) & Comoros, Democratic Republic of Congo, Republic of Congo, \\
& Côte d'Ivoire, The Gambia, Ghana, Guinea, Guinea Bissau, \\
& Honduras, Lao PDR, Liberia, Madagascar, Malawi, Myanmar, \\
& Rwanda, São Tomé and Príncipe, Sierra Leone, Somalia, \\
& Sudan, Togo, and Zambia. \\
& Albania, Armenia, Azerbaijan, Bangladesh, Cambodia, Cape \\
& Verde, Djibouti, Dominica, Equatorial Guinea, Georgia, Haiti, \\
Non-HIPC PRGF Countries (24) 1/ & Kenya, Kyrgyz Republic, Lesotho, Macedonia, FYR, \\
& Moldova, Mongolia, Nepal, Pakistan, Sri Lanka, Tajikistan, \\
& Vietnam, Yemen, and Zimbabwe. \\
\hline
\end{tabular}

1/ Four sustainable HIPCs (Angola, Kenya, Vietnam, and Yemen) are treated as non-HIPC countries in this paper.

A brief discussion of the data is warranted. The World Bank's CPIA index assesses the quality of a country's present policy and institutional framework. It has 20 indicators in four broad categories: economic management, structural policies, polices for social inclusion and equity, and public sector management and institutions. Countries are rated on their current status with scores from 1 (lowest) to 6 (highest). Annual country ratings from 1998, in 5 quintiles (the first to the fifth), are publicly available. The KKM governance indicators cover about 200 countries in six areas: voice and accountability, political stability, government effectiveness, regulatory quality, rule of law, and control of corruption. A country's rating is presented as a point estimate with a margin of error. The point estimate normally falls between -2.5 (lowest) and 2.5 (highest), with the world average at zero.

DRI has monitored the HIPCs' debt management capacity since $1997,{ }^{9}$ and recently improved its methodology to evaluate debt management capacity. This revised methodology has been expanded to include 14 different evaluation areas that range from transparency and political commitment to new financing policy and institutional and legal issues. This assessment is based on countries' self-evaluation with ranking from 1 (very poor) to 5 (excellent). The closer to 5 a country is, the closer to ideal international standards. An overall debt management capacity ranking is a simple average of the 14 individual indicators.

Cross-country data on export composition over long time periods are not readily available. ${ }^{10}$ This paper uses cross-country data compiled by the Fund's Research Department in 2001, which offer only a snapshot in time. Since countries' export structures change only slowly,

${ }^{9}$ DRI does not construct data on debt management capacity for non-HIPC countries.

10 The World Bank's WITS database contains trade data for 67 developing and developed countries at the industry level over the period 1976-1999. 
however, such a snapshot is nonetheless useful. Detailed export composition data of individual completion point countries are obtained from IMF country teams. Cross-country data of central government revenue-to-GDP ratios (excluding grants) are compiled from IMF departmental databases and country papers.

\section{Cross-Country Comparisons}

To set the stage, this section starts with a discussion of the macroeconomic performance of completion point countries. It then compares indicators on policy and institutional frameworks, debt management capacity, export structure, and fiscal revenue mobilization among three groups of low-income countries: completion point countries, other HIPCs, and non-HIPC PRGF countries. Differences among completion point countries themselves are also explored.

\section{A. Macroeconomic Performance}

Low-income countries suffered setbacks in growth and macroeconomic stability between the late 1970s and the late 1980s (Figure 1). This was particularly pronounced for the HIPC countries. HIPCs on average saw negative growth, double-digit inflation, rising budget and current account deficits, and declining reserves during the early to mid-1980s. This was also the period during which HIPCs saw their debt burden increase markedly.

Since the late 1980s, the HIPC completion point countries have experienced steady improvement in macroeconomic performance. The median growth accelerated to about 5 percent in the late 1990s from less than 1 percent in the early 1980s, while the median inflation rate decelerated from 15 percent in the early 1980s to just 5 percent in the late $1990 \mathrm{~s}$, the lowest level in more than two decades. The median fiscal deficit narrowed from about 7 percent of GDP in the early 1980s to below 4 percent recently. International reserves, on average, rose from about one month of imports to about five months of imports during the same period. Furthermore, strong macroeconomic performance among completion point countries was fairly broad-based, with the variances of major indicators in the 1990s falling to less than half of the levels in the 1980s.

The strengthening macroeconomic performance in completion point countries was even more pronounced when compared with other low-income countries, particularly with other HIPCs. ${ }^{11}$ In general, completion point countries started with the worst macroeconomic indicators among the three groups in the early 1980s. However, by the mid- to late 1990s, completion point countries emerged with the highest real GDP growth, lowest inflation, lowest fiscal deficits in percent of GDP, and highest ratios of international reserves in months of imports.

Among major macroeconomic indicators, external current account developments in completion point countries warrant special attention. Since the mid-90s, completion point countries have experienced, on average, large current account deficits of about 8 percent of GDP. The

${ }^{11}$ This may well reflect a degree of self-selection, i.e., HIPC countries with better macroeconomic performance have been able to reach the completion point earlier. 
combination of widening current account deficits and accumulation of international reserves points to increasing capital flows to completion point countries.

Figure 1. Macroeconomic Stability and Growth in Low-Income Countries 1/
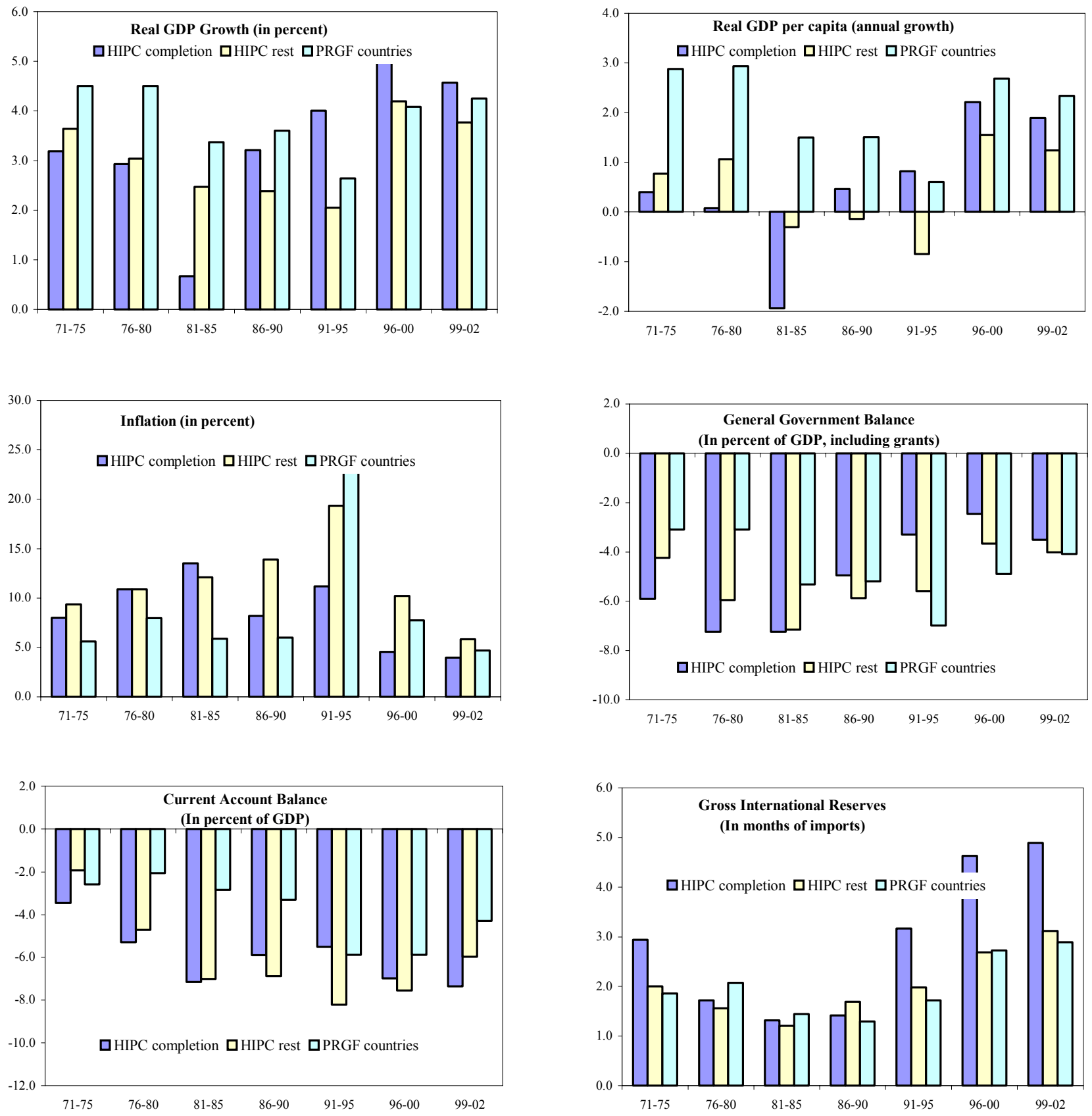

Source: WEO.

$1 /$ Median value of the variables for the country groupings.

Indeed, resource flows to completion point countries have generally been on a rising trend since the mid-1980s. The other HIPC countries and PRGF countries, however, saw their shares 
drop since the mid-1990s (Figure 2a and 2b). As the decline of net transfers to PRGF countries was particularly large, total net transfers to low-income countries as a whole started to decline since 1997, after the HIPC Initiative was launched. ${ }^{12}$

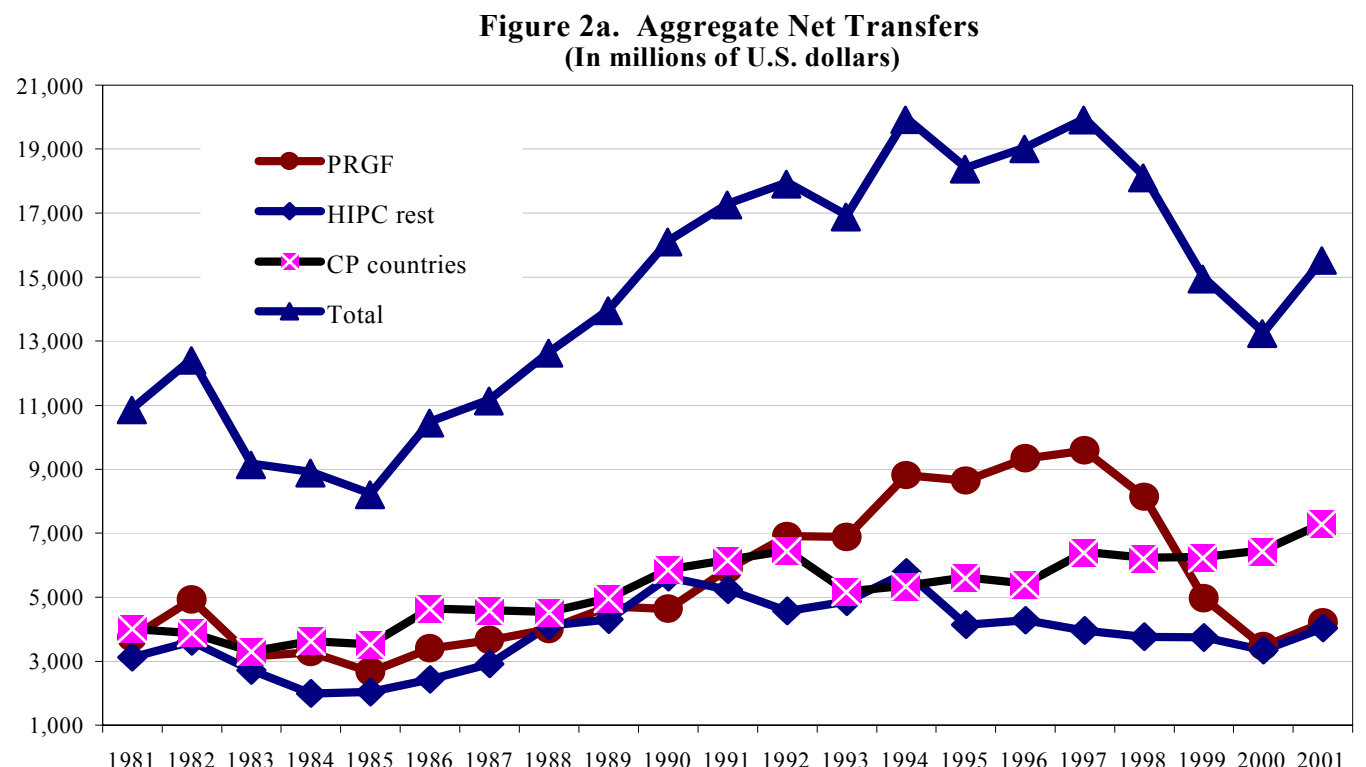

Figure 2b. Share of Aggregate Net Transfers

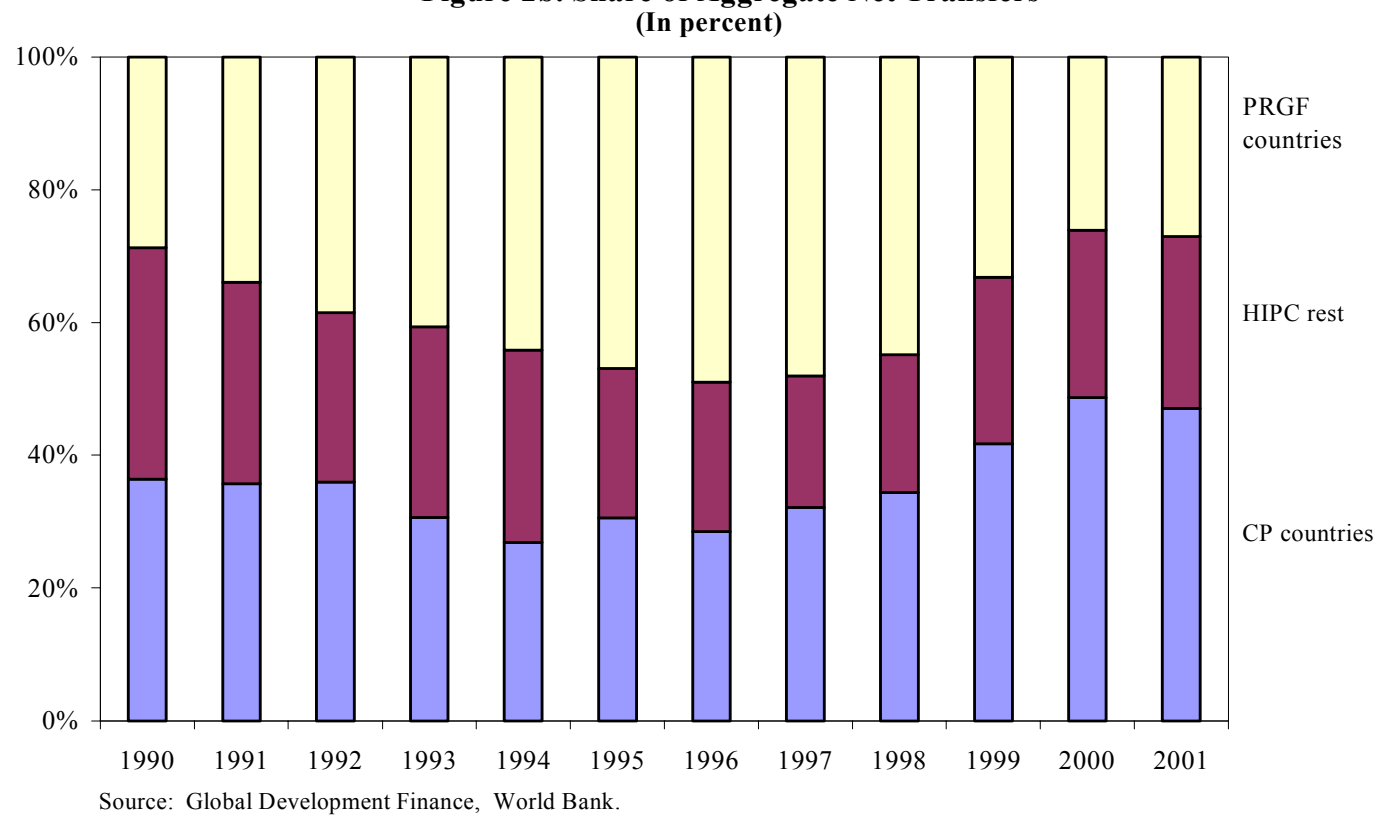

${ }^{12}$ Aggregate net transfers are defined as loan disbursements, plus foreign direct investment, portfolio equity flows, and official grants, minus FDI profits, and loan principal and interest repayments. 


\section{B. Policy and Institutional Frameworks}

Completion point countries are found to enjoy better policy and institutional frameworks than other HIPCs and non-HIPC PRGF countries for all years with available data. ${ }^{13}$ In general, they have consistently had higher CPIA rankings than the other two groups (Figure 3a and Table 2) since 1998. Not surprisingly, other HIPCs always have the lowest average ranking among the three. The median ranking among each group has shown no change at all since 1998, indicating the long-term nature of improving policy and institutional frameworks. Similar conclusions can also be drawn using KKM governance indicators (Figure $3 \mathrm{~b}$ and Table 3 ). ${ }^{14}$ Completion point countries have had the highest average indicators and other HIPCs the lowest in all six evaluation areas from 1996 to 2002 . The overall governance indicators for all three groups of countries also experienced some declines during the period. ${ }^{15}$

Completion point countries' relatively better policy and institutional frameworks among lowincome countries should not become a matter of complacency. As the average KKM governance indicators of about 200 countries are always zero by construction, negative governance indicators of completion point countries in all six areas signal that their policy and institutional frameworks are still in fairly poor shape compared to those of many other countries in the world. ${ }^{16}$ Moreover, compared with regular PRGF countries, while completion point countries fare relatively well in the areas of voice and accountability, and political stability, they fare less well in terms of a number of other variables, including government effectiveness, rule of law, and control of corruption, that have been found to have an important bearing on the investment climate. Thus, strengthening policy and institutional frameworks remains a longterm challenge for completion point countries.

${ }^{13}$ The result may well reflect the fact that, in general, HIPC countries with stronger policy and institutional frameworks are able to reach the completion point earlier. It does not tell us whether the HIPC Initiative has helped improve policy and institutional frameworks.

14 This suggests that the CPIA index and KKM governance indicators are correlated. However, the presence of margins of error in KKM indicators suggests that interpretation of rankings of the countries based on the point estimates should not be stretched too far.

${ }^{15}$ Interpreting changes in countries' estimates over time should be taken with caution. Because of the statistical methodology in deriving KKM governance indicators, changes of estimates over time could be attributed to 4 factors: changes in the score assigned to a country, addition of new data sources, changes of the sample size, and changes in the weights in the aggregation procedure. For details please see the KKM paper.

${ }^{16}$ A country's rating in quintiles reflects its relative ranking of policy and institutions among the 81 low-income countries which are IDA-eligible. Therefore, one can not draw the conclusion that a ranking in the first quintile indicates policy and institutional frameworks up to international standards. 

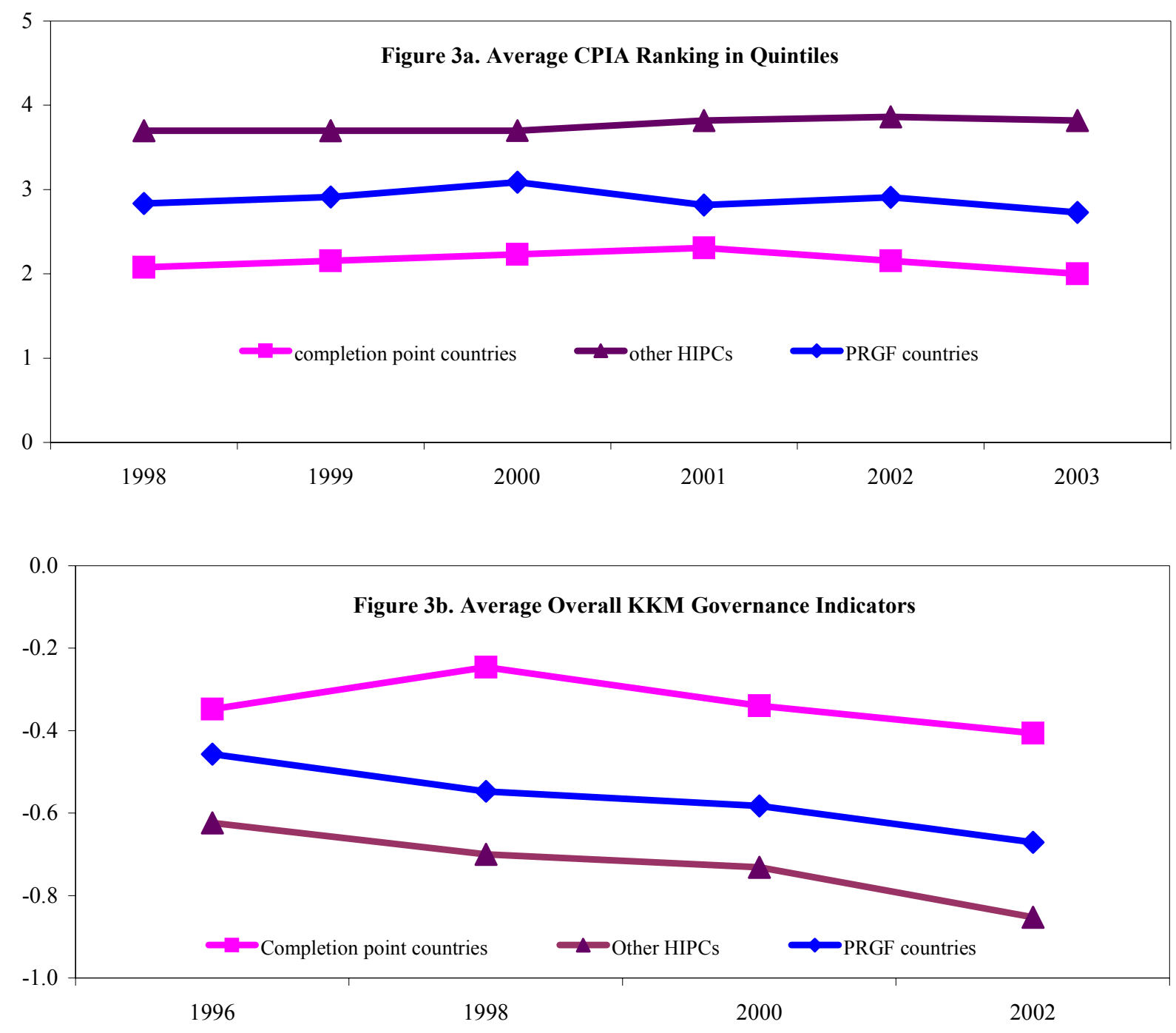

The quality of policy and institutional frameworks varies considerably among completion point countries themselves. At one end of the spectrum, a few countries, such as Mauritania, Senegal, Tanzania, and Uganda, have consistently landed in the first quintile of the CPIA index during the last few years. At the other end, Niger has been stuck at the fourth quintile, the average level of other HIPCs that have not yet exited from the HIPC Initiative. While some countries like Mali and Nicaragua experienced steady improvement in policy and institutional frameworks, Ethiopia and Guyana saw their rankings drop from the top quintile in 1998 to the third/fourth quintile recently.

\section{Debt Management Capacity}

Sound debt management capacity is important for HIPCs to achieve and maintain debt sustainability. The 2003 indicators constructed by Debt Relief International show that completion point countries in general have better debt management capacity than other HIPCs 
(Figure 4). The overall debt management indicator of completion point countries averages 3.3 out of a possible 5. This compares to an average of 2.8 among other HIPCs. Moreover, completion point countries, on average, appear to outperform other HIPCs in all 14 areas evaluated.

Nevertheless, completion point countries share a similar pattern of debt management weaknesses with other HIPCs, albeit to a lesser extent. Both completion point countries and other HIPCs score relatively high in basic debt management skills such as recording, disbursement, and servicing. However, the legal framework, risk analysis and transparency appear weak and inadequate across all HIPC countries, and will need to be strengthened for completion point countries to maintain debt sustainability after exiting from the HIPC Initiative.

As with policy and institutional frameworks, debt management capacity among completion point countries displays a large degree of unevenness (Figures 5-17). Tanzania stands out as the best performer, with higher-than-average scores in all 14 evaluation areas. Overall, Tanzania scores 4.2 out of a possible 5, significantly higher than the group average of 3.3. On the other hand, the debt management capacity of Guyana, Mauritania and Niger is found to lag behind seriously. Their levels of debt management capacity are not only below the group average of completion point countries in every assessment area, but also below the average of other HIPCs in many aspects. The remaining completion point countries lie in between the two ends, with differing weak areas.

Figure 4. Debt Management Capacity of HIPCs (group average)

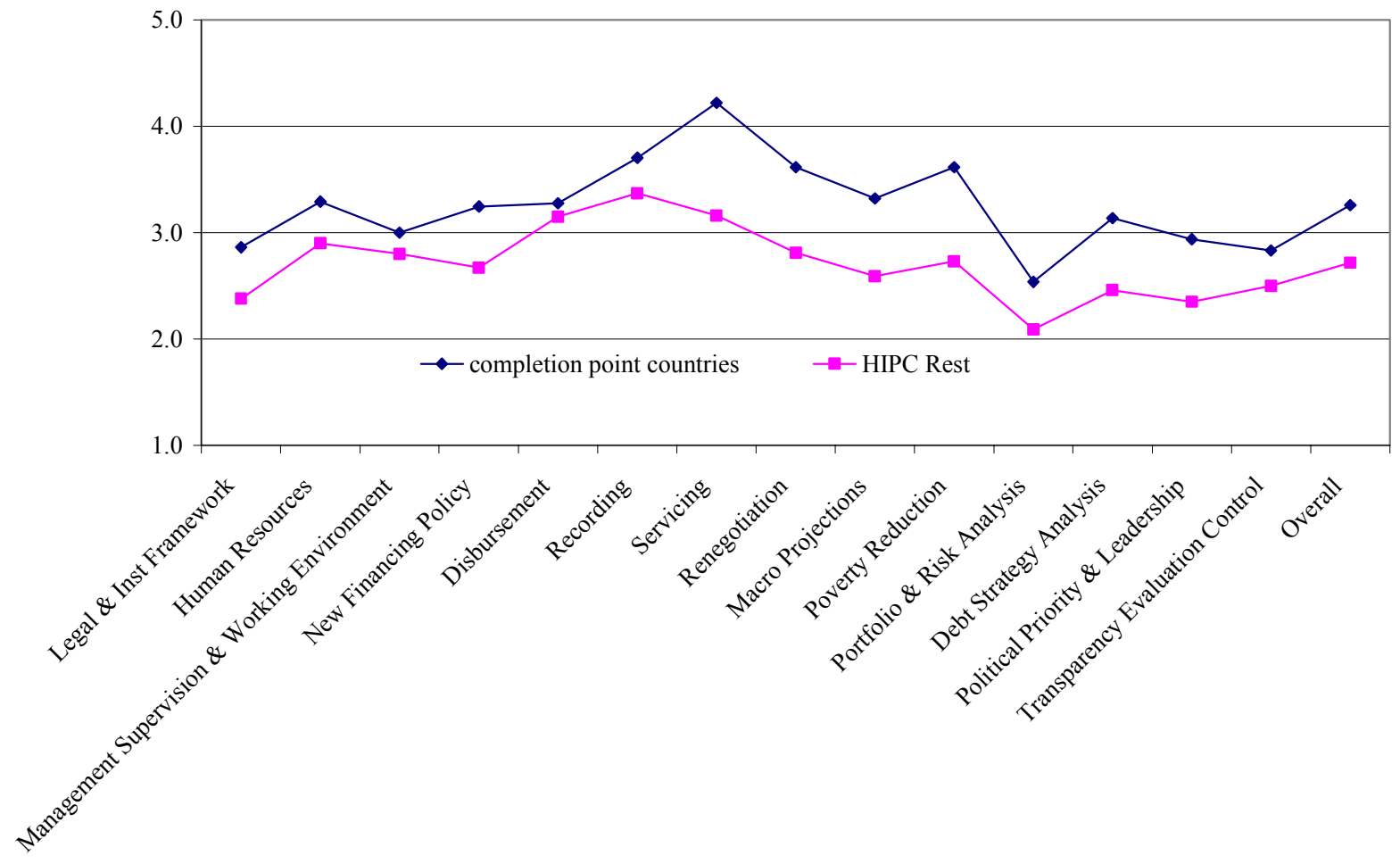




\section{Export Diversification}

This section examines completion point countries' potential vulnerability to terms of trade shocks. In particular, countries with narrow export bases tend to be more vulnerable to external shocks. The share of the top three commodity exports in total exports is calculated to measure a country's degree of export diversification. The higher the share, the narrower a country's export base and the more vulnerable it is to terms of trade shocks.

On export diversification, the top three commodity exports accounted for, on average, about 45 percent of total exports of goods and services in completion point countries in 2001 (Table 4). The share is about the same for other HIPCs. This compares to just about 20 percent in nonHIPC PRGF countries, highlighting the HIPCs' continued vulnerability to terms of trade shocks, even for countries that have exited from the HIPC Initiative. One commodity alone accounted for, on average, about 30 percent of total exports of goods and services in both completion point countries and other HIPCs, compared to just 16 percent in regular PRGF countries.

A close look at completion point countries' private current transfers and export of services also reveals their continued reliance on commodity exports and vulnerability to terms of trade shocks. During 1999-2002, private current transfers and exports of services among completion point countries averaged about 14 percent and 29 percent of total exports of goods and services. These compare to 22 percent and 33 percent among non-HIPC PRGF countries, and 10 percent and 24 percent among other HIPCs.

As shown in Figure 5-17, completion point countries' export structures remain weak. Commodities make up most of their exports, while exports of manufactured goods are limited at best. Exports in a number of completion point countries have been consistently dominated by just one or two commodities for years, for example, cotton in Benin and Burkina Faso, coffee in Ethiopia, iron ore and fish in Mauritania, cotton and gold in Mali. In some other countries where export structures have changed somewhat, it is often the case that traditional commodity exports have been surpassed by new commodities. For example, gold has quickly surpassed coffee and cotton to become Tanzania's number one export recently. Mozambique and Nicaragua have had sizeable exports of manufactured products, but they have not been able to widen their shares over the years.

HIPCs' reliance on a few commodity exports sheds some light on why they fell into the debt trap in the first place. Their narrow export bases have left them particularly vulnerable to terms of trade shocks. Development of a diversified export base thus remains a long-term task for all HIPCs, including completion point countries. They will need to pursue structural adjustment policies and create an environment conducive to foreign direct investment and, ultimately, broad-based export growth.

\section{E. Fiscal Revenue Mobilization}

This section conducts a simple cross-country comparison of fiscal revenue mobilization in completion point countries vs. other low-income countries. In the context of achieving external debt sustainability, fiscal revenue mobilization matters because countries with a low degree of 
fiscal revenue mobilization have to rely more on external aid flows, which can be very volatile, and external borrowing, which can be expensive and put their debt sustainability at risk, to meet their expenditure needs. Moreover, a country's ability to deal with shocks will be constrained if its fiscal revenue mobilization is relatively weak. This paper uses the central government revenue-to-GDP ratio (excluding grants) to capture a country's degree of fiscal revenue mobilization.

These data suggest that, in terms of fiscal revenue mobilization, HIPC completion point countries are not in a more favorable position, even compared with regular PRGF countries (Table 4). Over the period 2000-2003, the average revenue-to-GDP ratio (excluding grants) among completion point countries is about 17.6 percent, compared to 21 percent among regular PRGF countries and 15 percent among the rest of HIPCs. ${ }^{17}$ Moreover, completion point countries in general have made only limited progress in revenue mobilization during the last decade, with their average revenue-to-GDP ratio rising slightly from around 15 percent in the early 1990s to about 17 percent recently (Table 5). While Ethiopia was able to almost double its revenue-to-GDP ratio, the ratios of many completion point countries showed only limited improvement during 1992-2002.

A close look at the revenue-to-GDP ratio of each individual completion point country yields some interesting results. First, Niger again stands out as the weakest performer among completion point countries. Niger has the lowest ratio of about 10 percent of GDP, followed by Burkina Faso, Tanzania, and Uganda (12 percent of GDP). Second, although Tanzania scores fairly high in the other three structural areas, it lags behind in fiscal revenue mobilization, even compared with many other HIPCs which have not yet reached the completion point. Third, Guyana appears to enjoy the highest revenue-to-GDP ratio among completion point countries, but this should be interpreted with caution. If measured against its external debt stock and service, Guyana's fiscal revenue mobilization appears relatively weak. As a matter of fact, Guyana qualified for the HIPC Initiative under the fiscal window. Guyana also has a fairly high current expenditure-to-GDP ratio of over 30 percent, suggesting that the GDP data might be underestimated.

\section{Concluding Remarks}

This paper reviewed policy and institutional frameworks, debt management capacity, export structures, and fiscal revenue mobilization in HIPC completion point countries. In comparison with other HIPC countries, completion point countries generally enjoy better policy and institutional frameworks and stronger debt management capacity. However, their policy and institutional frameworks are still fairly poor when compared to world average levels, and their debt management capacity remains some distance from international standards. Moreover, completion point countries' export bases, on average, are no more diversified than those in other HIPCs and, in fact, are much narrower than those in non-HIPC PRGF countries, highlighting their continued vulnerability to external shocks. On the fiscal side, completion point countries

${ }^{17}$ Weak revenue mobilization in HIPCs is no surprise given their narrow production and export bases. 
still lag behind considerably in revenue mobilization, even compared with regular PRGF countries. In sum, countries exiting from the HIPC Initiative still have a long way to go to achieve the underpinning necessary for long-term debt sustainability.

There is no single completion point country that fares relatively well in all four structural indicators. Tanzania appears to enjoy relatively better policy and institutional frameworks and stronger debt management capacity, and it has also become much less dependent on its traditional exports such as coffee and cotton. However, its revenue-to-GDP ratio has averaged around 12 percent since 1992, even lower than the average of other HIPCs that have not yet reached their completion point. At the other end of the spectrum, prospects for long-term sustainability in Niger look worrisome. Its policy and institutional frameworks and debt management capacity compare unfavorably even with those of many other HIPCs that have not yet exited from the HIPC Initiative. Moreover, it has made little progress on export diversification, and its fiscal revenue-to-GDP ratio remains low at 10 percent. Other completion point countries all have weaknesses in one area or another, although the seriousness of their problems differ.

Completion point countries will continue to face a dilemma given their large priority financing needs for development on the one hand, and the need to maintain long-term debt sustainability on the other. To achieve debt sustainability, they should maintain macroeconomic stability and deepen reforms to improve policy and institutional frameworks, strengthen debt management, mobilize domestic revenues, and create an environment conducive to attracting foreign direct investment and diversifying exports. The mix between debt and grant financing must be closely monitored by both borrowers and creditors to ensure that the potentially large financing needs associated with meeting the Millennium Development Goals do not give rise to a renewed excessive buildup of debt.

Finally, a word of caution. Given the importance of structural factors in achieving and maintaining long-term external debt sustainability, this paper has sought to assess where the HIPC completion point countries stand in these areas based on cross-country indicators. Unfortunately, the availability of such data is rather limited, and requires reliance on highlyaggregated indicators that in some cases are based on self-evaluation. While this kind of crosscountry analysis can provide a broad indication of recent trends, it does not substitute for indepth country-specific analysis as a basis for policy advice on how to improve a country's prospects for achieving and maintaining long-term debt sustainability. 
Table 2. CPIA Index of Completion Point Countries (In quintiles)

\begin{tabular}{|c|c|c|c|c|c|c|}
\hline Country & 1998 & 1999 & 2000 & 2001 & 2002 & 2003 \\
\hline Benin & 2 & 2 & 2 & 2 & 2 & 2 \\
\hline Bolivia & 1 & 2 & 2 & 3 & 2 & 2 \\
\hline Burkina Faso & 3 & 3 & 3 & 2 & 2 & 2 \\
\hline Ethiopia & 1 & 2 & 4 & 3 & 3 & 3 \\
\hline Guyana & 1 & 1 & 2 & 3 & 4 & 3 \\
\hline Mali & 3 & 3 & 3 & 4 & 2 & 2 \\
\hline Mauritania & 2 & 1 & 1 & 1 & 1 & 1 \\
\hline Mozambique & 3 & 2 & 2 & 2 & 3 & 3 \\
\hline Nicaragua & 2 & 3 & 3 & 3 & 2 & 1 \\
\hline Niger & 4 & 4 & 4 & 4 & 4 & 4 \\
\hline Senegal & 2 & 2 & 1 & 1 & 1 & 1 \\
\hline Tanzania & 2 & 2 & 1 & 1 & 1 & 1 \\
\hline Uganda & 1 & 1 & 1 & 1 & 1 & 1 \\
\hline average & 2.1 & 2.2 & 2.2 & 2.3 & 2.2 & 2.0 \\
\hline median & 2.0 & 2.0 & 2.0 & 2.0 & 2.0 & 2.0 \\
\hline \multicolumn{7}{|c|}{ Memorandum items } \\
\hline \multicolumn{7}{|l|}{ HIPC rest } \\
\hline average & 3.7 & 3.7 & 3.7 & 3.8 & 3.9 & 3.8 \\
\hline median & 4.0 & 4.0 & 4.0 & 4.0 & 4.0 & 4.0 \\
\hline \multicolumn{7}{|c|}{ Non-HPIC PRGF } \\
\hline average & 2.8 & 2.9 & 3.1 & 2.8 & 2.9 & 2.7 \\
\hline median & 3.0 & 3.0 & 3.0 & 3.0 & 3.0 & 3.0 \\
\hline
\end{tabular}

Source: World Bank. 
Table 3. Group Average of KKM Governance Indicators

\begin{tabular}{|c|c|c|c|c|}
\hline & 2002 & 2000 & 1998 & 1996 \\
\hline & \multicolumn{3}{|c|}{ Voice and Accountability } & \\
\hline Completion point countries & -0.2 & -0.1 & -0.2 & -0.2 \\
\hline The rest of HIPCs & -0.9 & -0.9 & -0.8 & -0.8 \\
\hline \multirow[t]{2}{*}{ PRGF countries } & -0.5 & -0.4 & -0.4 & -0.4 \\
\hline & \multicolumn{3}{|c|}{ Political Stability } & \\
\hline Completion point countries & -0.2 & -0.3 & -0.2 & -0.2 \\
\hline The rest of HIPCs & -0.9 & -0.8 & -0.8 & -0.6 \\
\hline \multirow[t]{2}{*}{ PRGF countries } & -0.6 & -0.5 & -0.5 & -0.3 \\
\hline & \multicolumn{3}{|c|}{ Government Effectiveness } & \\
\hline Completion point countries & -0.6 & -0.4 & -0.2 & -0.5 \\
\hline The rest of HIPCs & -0.9 & -0.8 & -0.7 & -0.7 \\
\hline \multirow[t]{2}{*}{ PRGF countries } & -0.6 & -0.7 & -0.6 & -0.5 \\
\hline & \multicolumn{3}{|c|}{ Regulatory Quality } & \\
\hline Completion point countries & -0.4 & 0.0 & 0.0 & -0.3 \\
\hline The rest of HIPCs & -0.8 & -0.5 & -0.6 & -0.6 \\
\hline \multirow[t]{2}{*}{ PRGF countries } & -0.6 & -0.4 & -0.5 & -0.5 \\
\hline & \multicolumn{3}{|c|}{ Rule of Law } & \\
\hline Completion point countries & -0.5 & -0.5 & -0.4 & -0.6 \\
\hline The rest of HIPCs & -0.9 & -0.8 & -0.8 & -0.7 \\
\hline \multirow[t]{2}{*}{ PRGF countries } & -0.6 & -0.6 & -0.5 & -0.4 \\
\hline & \multicolumn{3}{|c|}{ Control of Corruption } & \\
\hline Completion point countries & -0.5 & -0.6 & -0.6 & -0.4 \\
\hline The rest of HIPCs & -0.8 & -0.7 & -0.7 & -0.5 \\
\hline \multirow[t]{2}{*}{ PRGF countries } & -0.7 & -0.7 & -0.6 & -0.5 \\
\hline & \multicolumn{3}{|c|}{ Overall } & \\
\hline Completion point countries & -0.4 & -0.3 & -0.2 & -0.3 \\
\hline The rest of HIPCs & -0.9 & -0.8 & -0.7 & -0.6 \\
\hline PRGF countries & -0.6 & -0.6 & -0.5 & -0.4 \\
\hline
\end{tabular}

Sources: The World Bank. 
Table 4. Export Diversification and Revenue Mobilization in Completion Point Countries (in percent)

\begin{tabular}{|c|c|c|c|}
\hline Country & $\begin{array}{l}\text { Share of top three } \\
\text { commodities in total } \\
\text { exports } 1 /\end{array}$ & $\begin{array}{c}\text { Share of top one } \\
\text { commodity in total exports } \\
1 /\end{array}$ & $\begin{array}{l}\text { Central government revenue } \\
\text { excluding grants in percent of } \\
\text { GDP } 2 / 3 \text { / }\end{array}$ \\
\hline$\overline{\text { Benin }}$ & 49 & 48 & 17 \\
\hline Bolivia & 22 & 8 & 17 \\
\hline Burkina Faso & 53 & 53 & 12 \\
\hline Ethiopia & 37 & 26 & 19 \\
\hline Guyana & 61 & 28 & 32 \\
\hline Mali & 74 & 38 & 14 \\
\hline Mauritania & 91 & 41 & 28 \\
\hline Mozambique & 69 & 44 & 14 \\
\hline Nicaragua & 22 & 16 & 23 \\
\hline Niger & 35 & 32 & 10 \\
\hline Senegal & 13 & 9 & 18 \\
\hline Tanzania & 12 & 8 & 12 \\
\hline Uganda & 44 & 42 & 12 \\
\hline average & 45 & 30 & 18 \\
\hline median & 44 & 32 & 17 \\
\hline \multicolumn{4}{|c|}{ Memorandum items: } \\
\hline \multicolumn{4}{|l|}{ HIPC rest } \\
\hline average & 45 & 32 & 15 \\
\hline median & 40 & 24 & 14 \\
\hline \multicolumn{4}{|c|}{ Non-HIPC PRGF } \\
\hline average & 20 & 16 & 21 \\
\hline median & 12 & 9 & 21 \\
\hline
\end{tabular}

Sources: IMF departmental databases, country papers and author's calculation.

1/ Based on data available as of December 2001, and calculated as ratio of total exports of goods and services in 2001.

2/ Annual average during 2000-2003.

$3 /$ In several countries where data of central government revenue are not readily available, general government data are used. 
Table 5. Central Government Revenue-to-GDP Ratios in Completion Point Countries During 1992-2002

\begin{tabular}{|c|c|c|c|c|c|c|c|c|c|c|c|}
\hline Country & 1992 & 1993 & 1994 & 1995 & 1996 & 1997 & 1998 & 1999 & 2000 & 2001 & 2002 \\
\hline Benin & 12.3 & 13.2 & 12.8 & 14.9 & 15.1 & 14.5 & 15.3 & 16.0 & 16.6 & 16.2 & 16.9 \\
\hline Bolivia & 15.3 & 16.2 & 16.7 & 16.6 & 17.5 & 17.0 & 17.7 & 17.9 & 18.0 & 17.4 & 17.0 \\
\hline Burkina Faso & 10.4 & 11.0 & 9.6 & 10.3 & 10.8 & 11.4 & 11.8 & 12.9 & 11.6 & 11.1 & 11.6 \\
\hline Ethiopia & 10.6 & 12.0 & 13.9 & 17.4 & 18.4 & 18.2 & 18.1 & 18.2 & 18.3 & 18.8 & 20.1 \\
\hline Guyana & 37.8 & 38.2 & 32.0 & 33.5 & 34.6 & 31.9 & 30.6 & 29.9 & 31.8 & 31.3 & 32.4 \\
\hline Mali & 13.2 & 12.9 & 11.7 & 10.0 & 12.7 & 12.9 & 13.1 & 13.2 & 12.9 & 13.2 & 15.1 \\
\hline Mauritania & 19.4 & 25.6 & 23.2 & 24.0 & 29.2 & 26.9 & 27.1 & 27.9 & 25.9 & 22.2 & $37.21 /$ \\
\hline Mozambique & 14.4 & 13.9 & 11.6 & 11.7 & 10.8 & 11.5 & 11.3 & 12.0 & 13.2 & 13.3 & 14.2 \\
\hline Nicaragua & 20.5 & 20.1 & 20.5 & 22.0 & 23.7 & 26.3 & 27.0 & 25.8 & 24.5 & 22.3 & 23.4 \\
\hline Niger & 8.2 & 7.3 & 6.1 & 7.2 & 7.8 & 8.4 & 9.1 & 8.8 & 8.6 & 9.3 & 10.6 \\
\hline Senegal & 18.4 & 16.6 & 14.9 & 16.4 & 16.6 & 16.9 & 16.8 & 17.3 & 18.1 & 17.8 & 18.9 \\
\hline Tanzania & 12.3 & 11.8 & 10.5 & 11.0 & 11.9 & 12.1 & 11.1 & 10.7 & 10.6 & 11.4 & 11.5 \\
\hline Uganda & 6.9 & 7.4 & 8.5 & 10.0 & 10.5 & 11.2 & 10.7 & 11.7 & 11.4 & 10.9 & 12.3 \\
\hline Average & 15.4 & 15.9 & 14.8 & 15.8 & 16.9 & 16.9 & 16.9 & 17.1 & 17.0 & 16.5 & 18.6 \\
\hline Maximum & 37.8 & 38.2 & 32.0 & 33.5 & 34.6 & 31.9 & 30.6 & 29.9 & 31.8 & 31.3 & 37.2 \\
\hline Minimum & 6.9 & 7.3 & 6.1 & 7.2 & 7.8 & 8.4 & 9.1 & 8.8 & 8.6 & 9.3 & 10.6 \\
\hline
\end{tabular}

Sources: IMF departmental databases, country papers, and author calculation.

1/ The sudden increase of Mauritania's ratio in 2002 was due to a jump of EU fish royalties. 
Figure 5. Benin

Debt Management Capacity

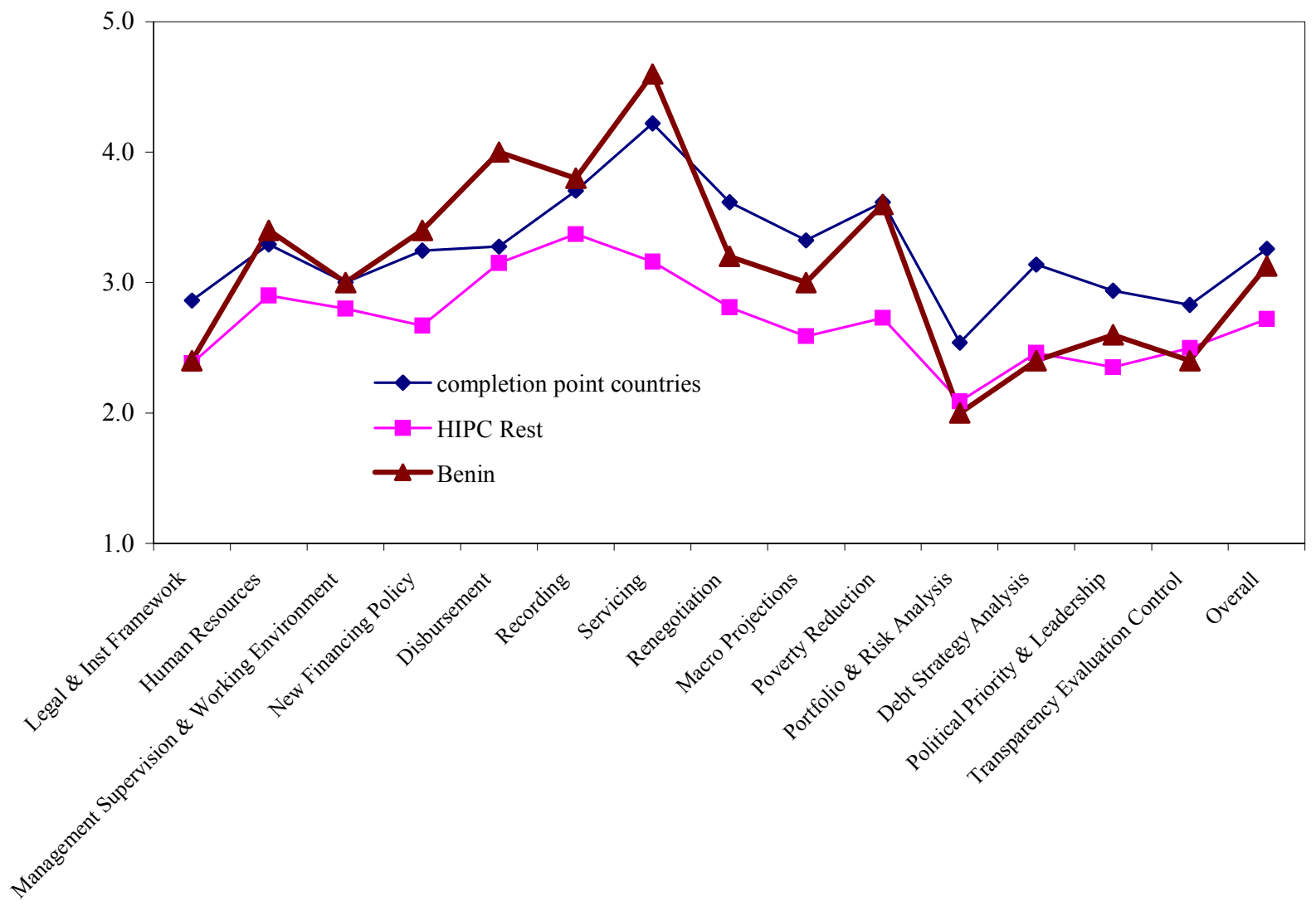

Export Composition

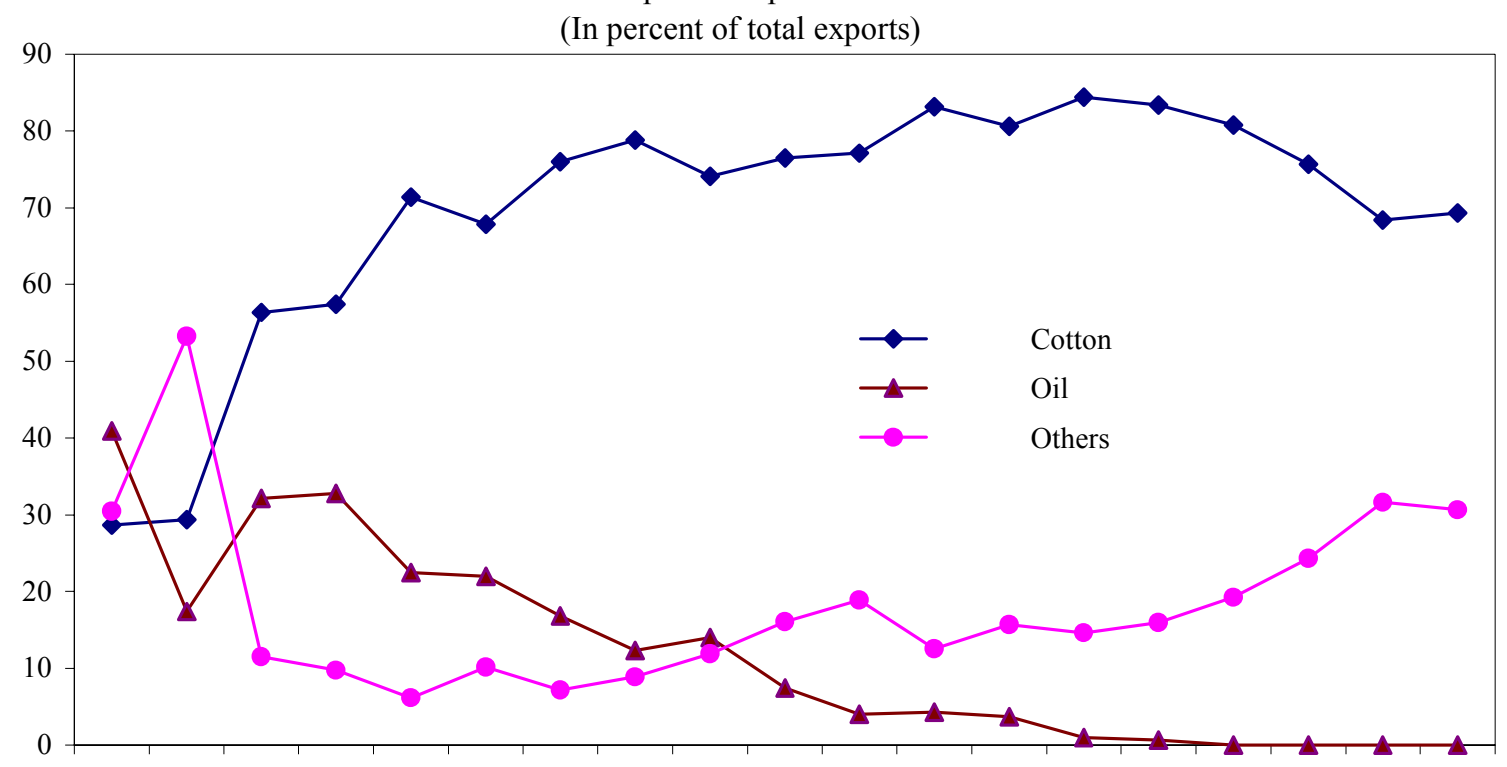

1985198619871988198919901991199219931994199519961997199819992000200120022003 
Figure 6: Bolivia

Debt Management Capacity

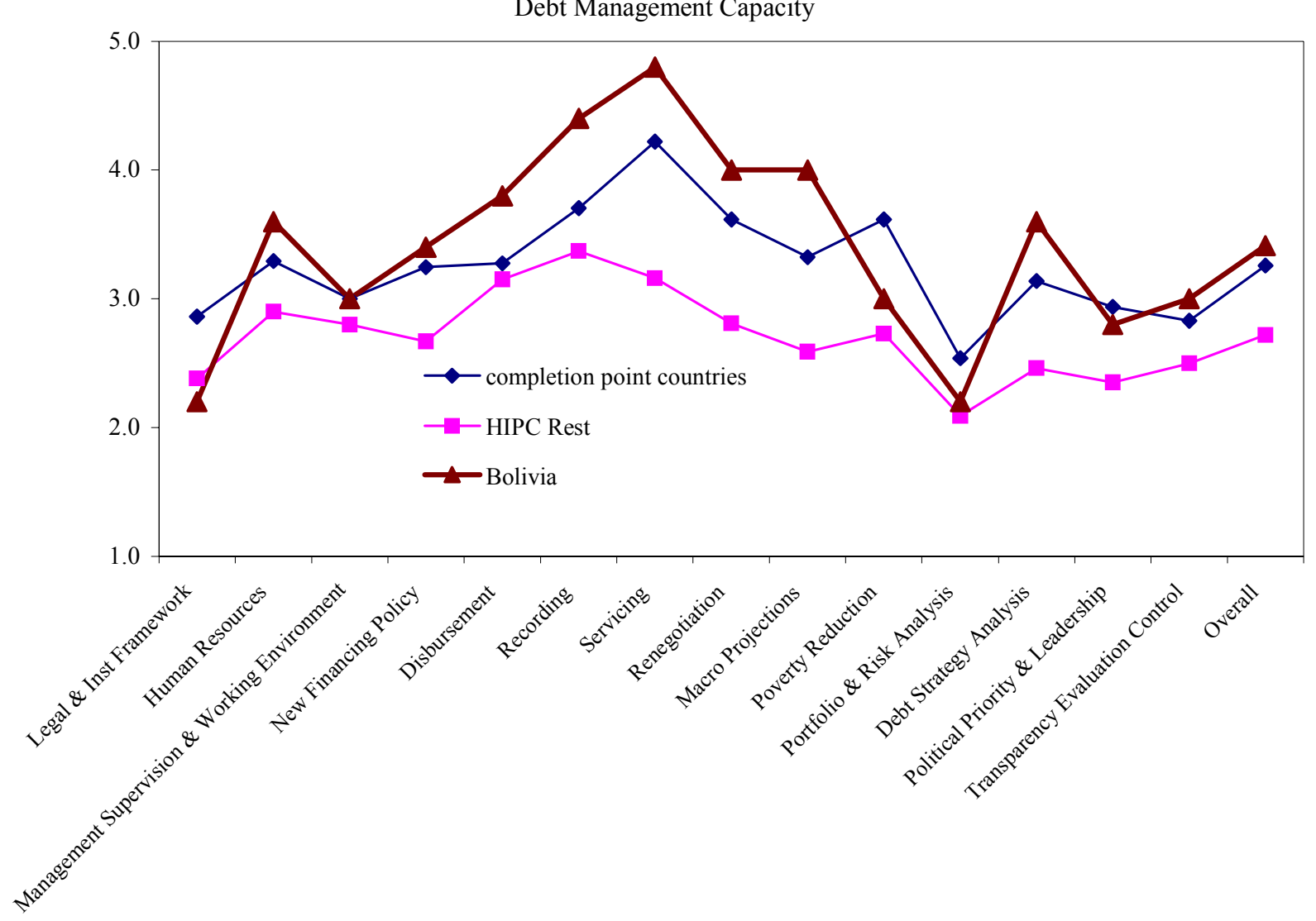

Export Composition

(In percent of total exports)

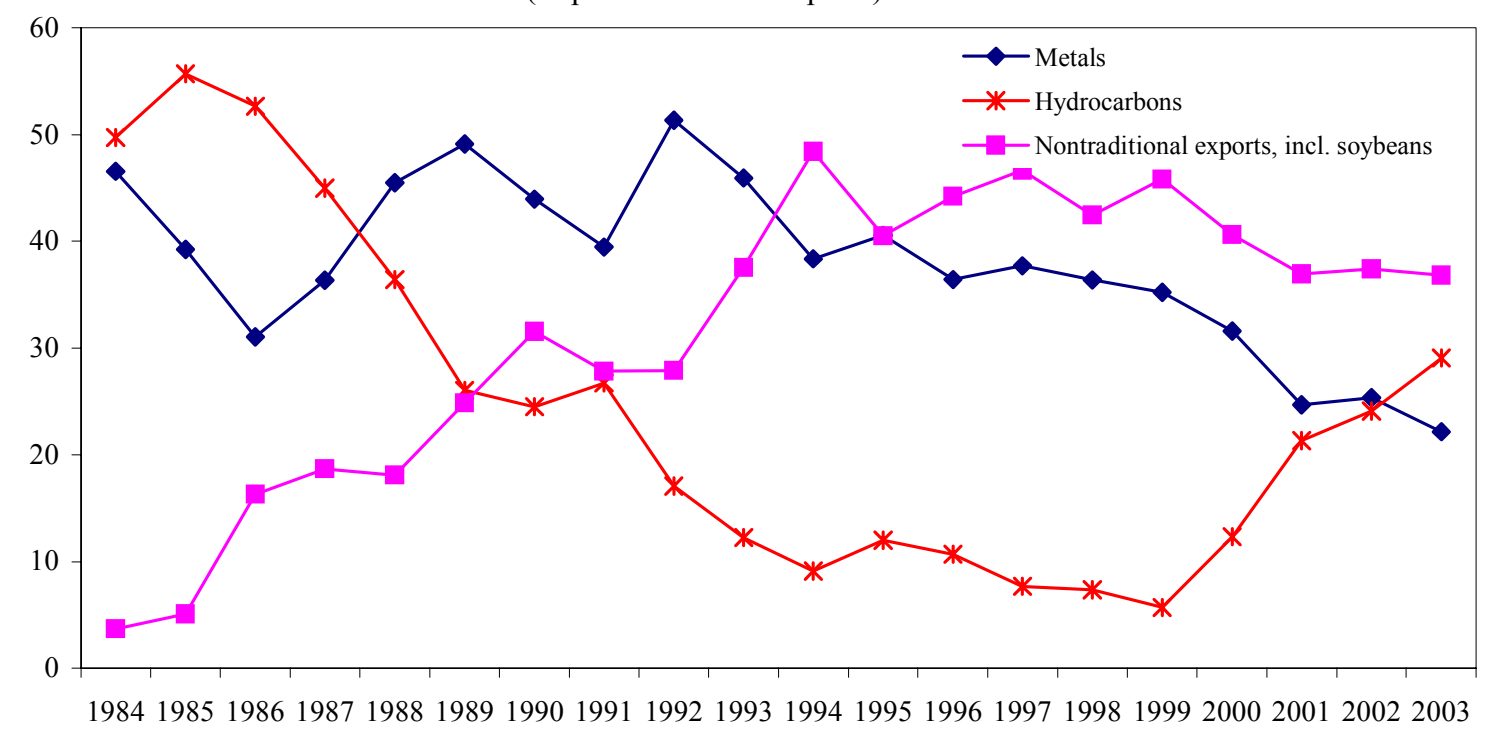


Figure 7: Burkina Faso

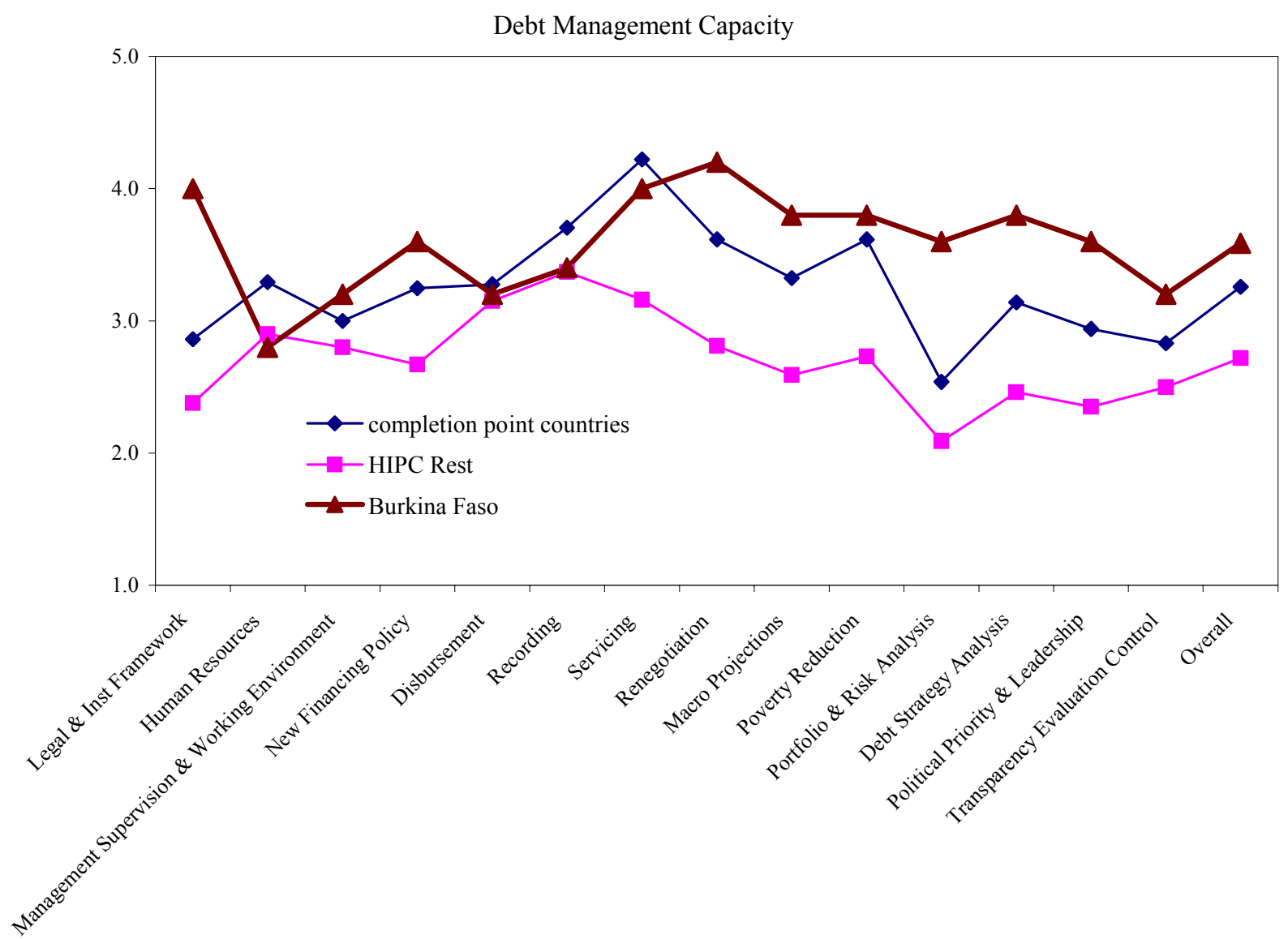

Export Composition

(In percent of total goods exports)

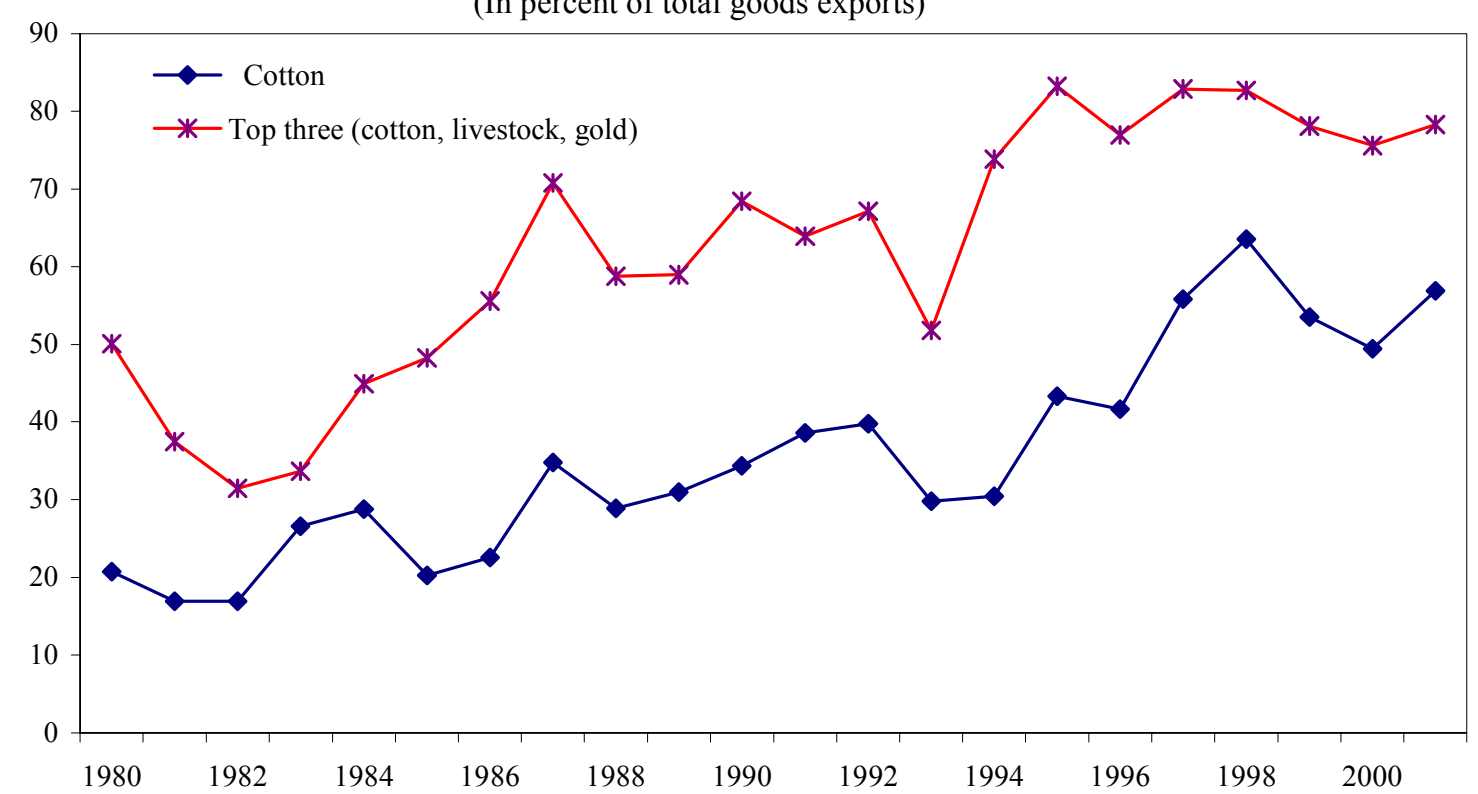


Figure 8: Ethiopia

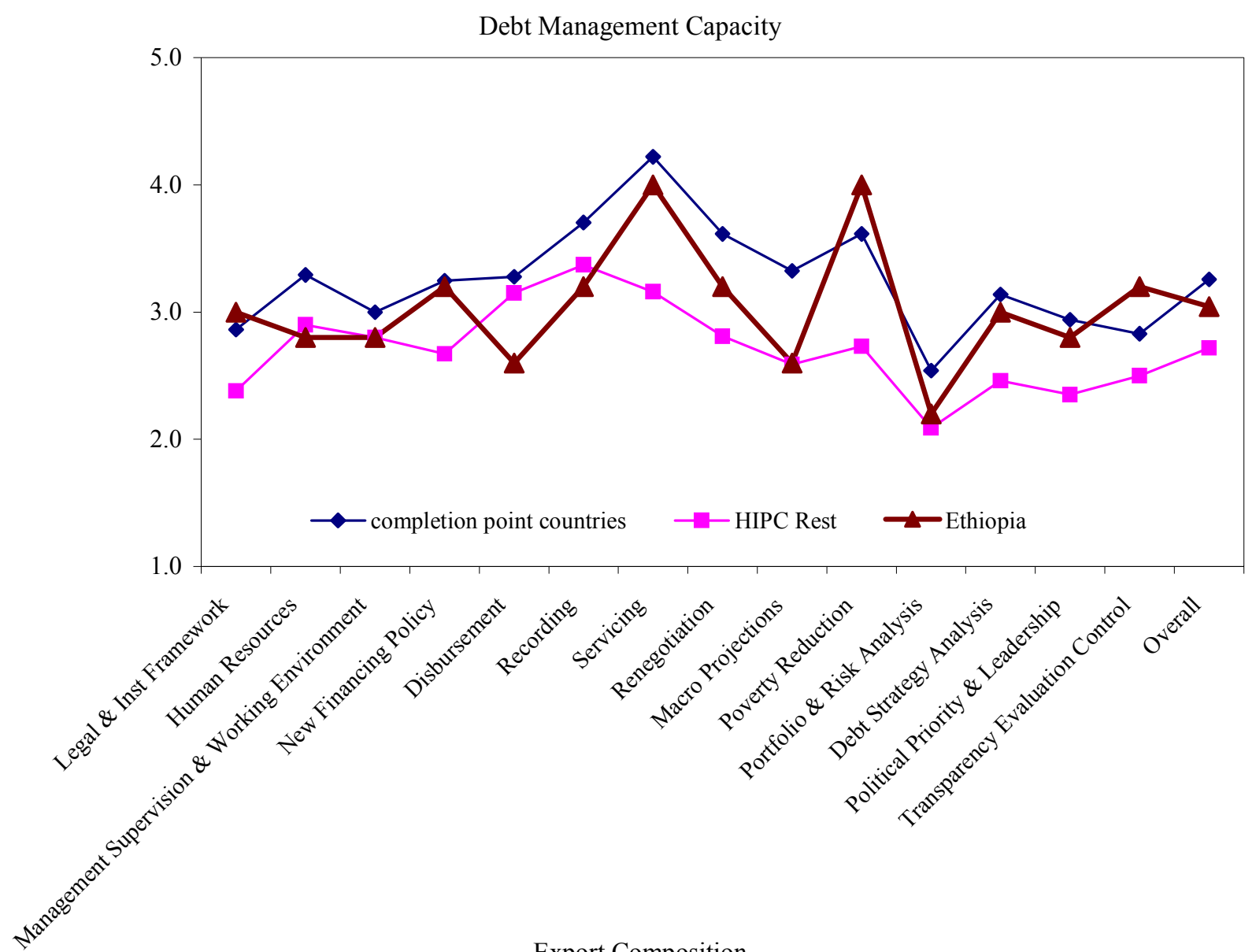

Export Composition

(In percent of total exports)

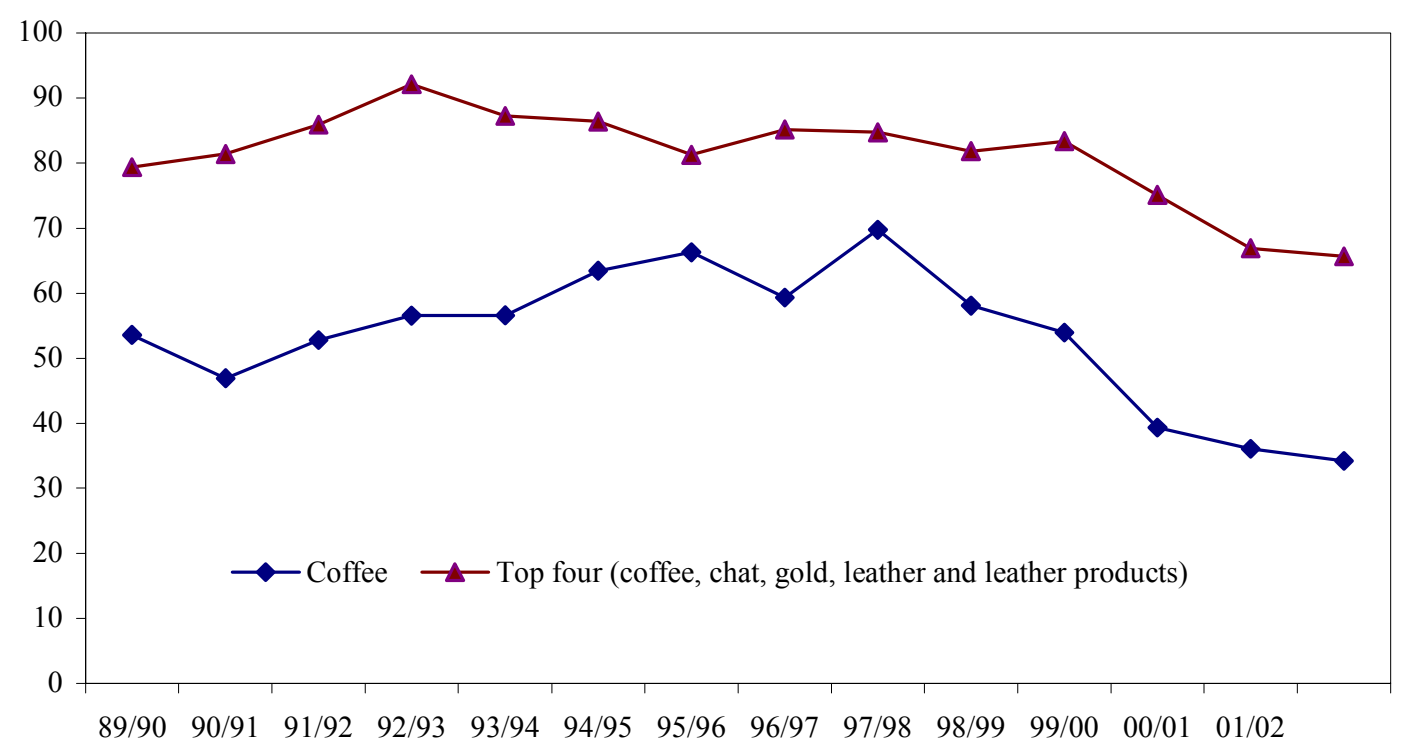


Figure 9: Guyana

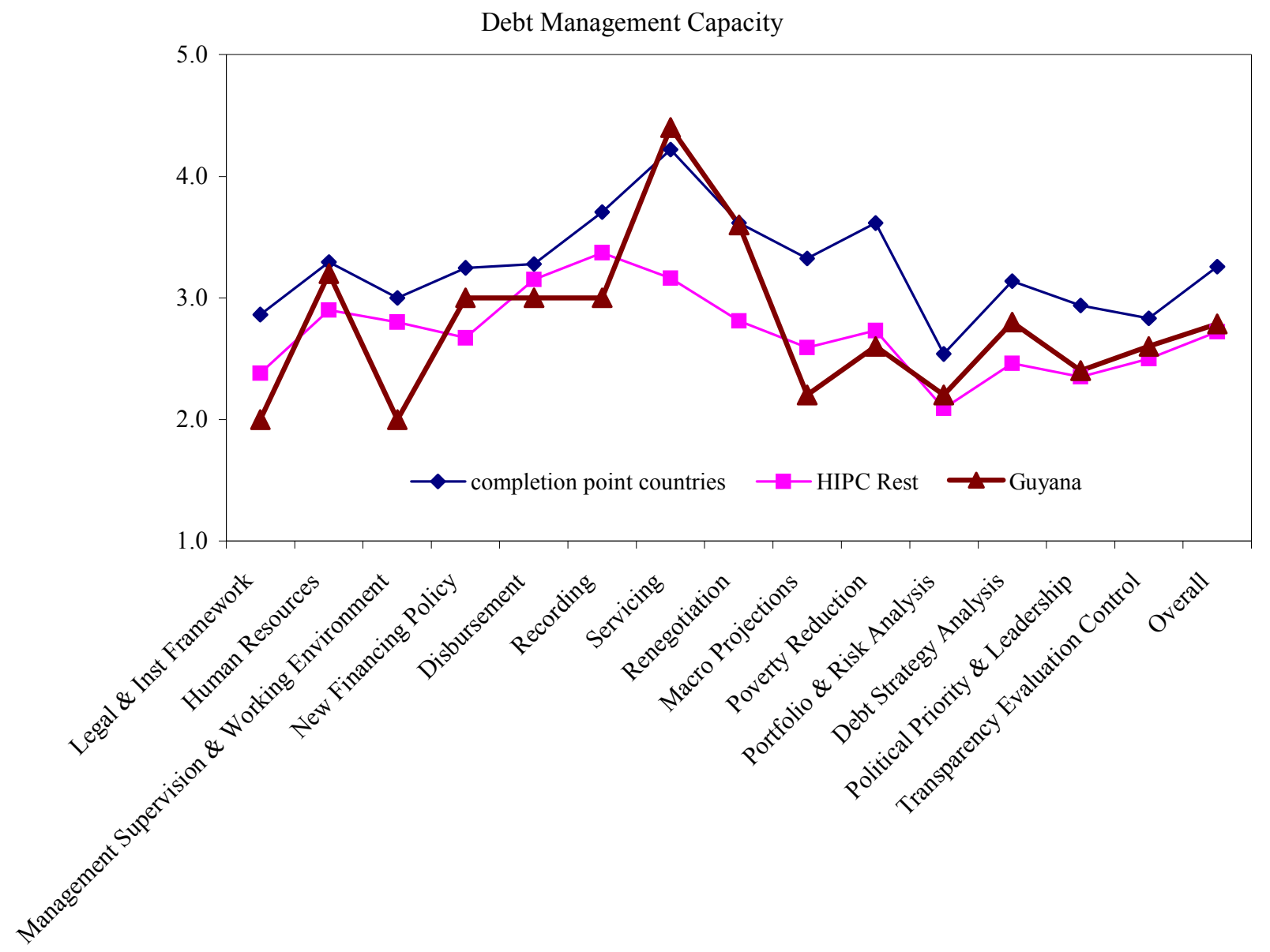

Export Composition

(In percent of total exports)

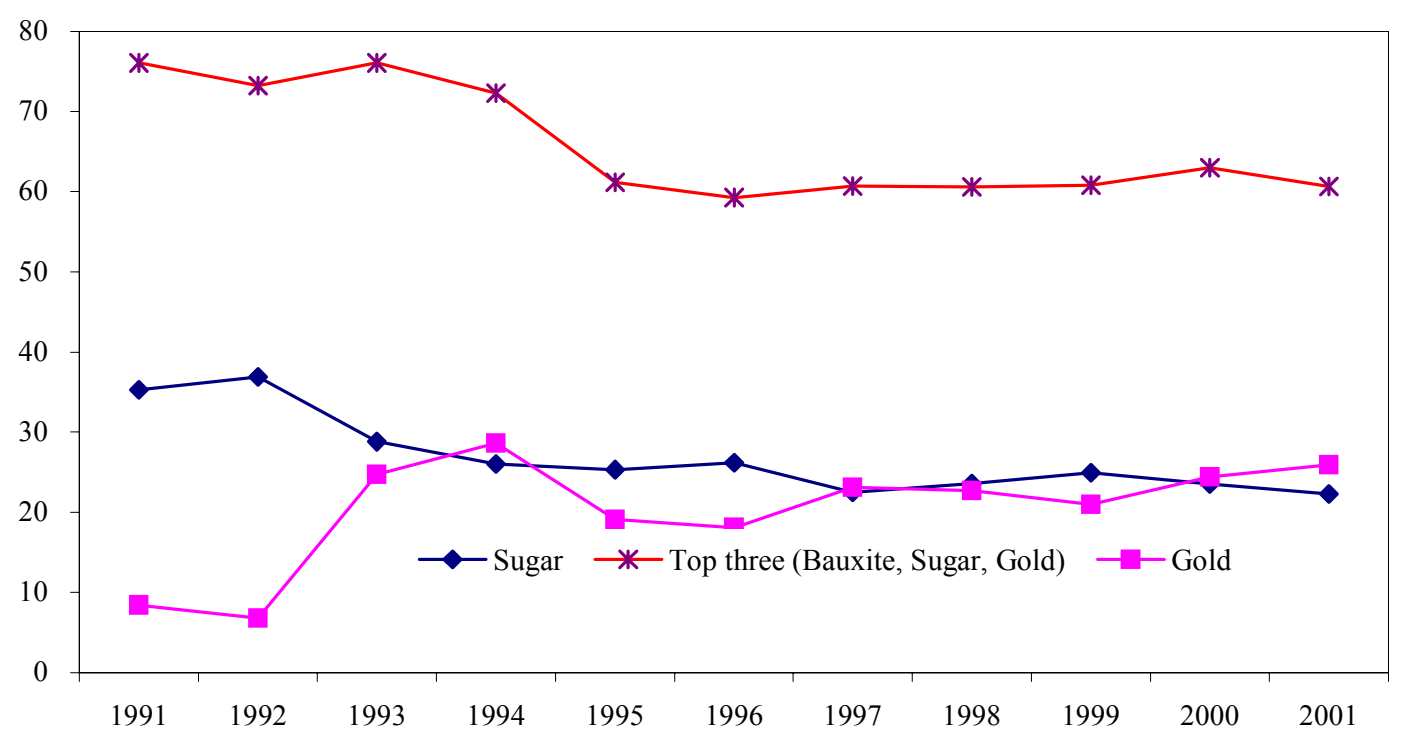


Figure 10: Mali

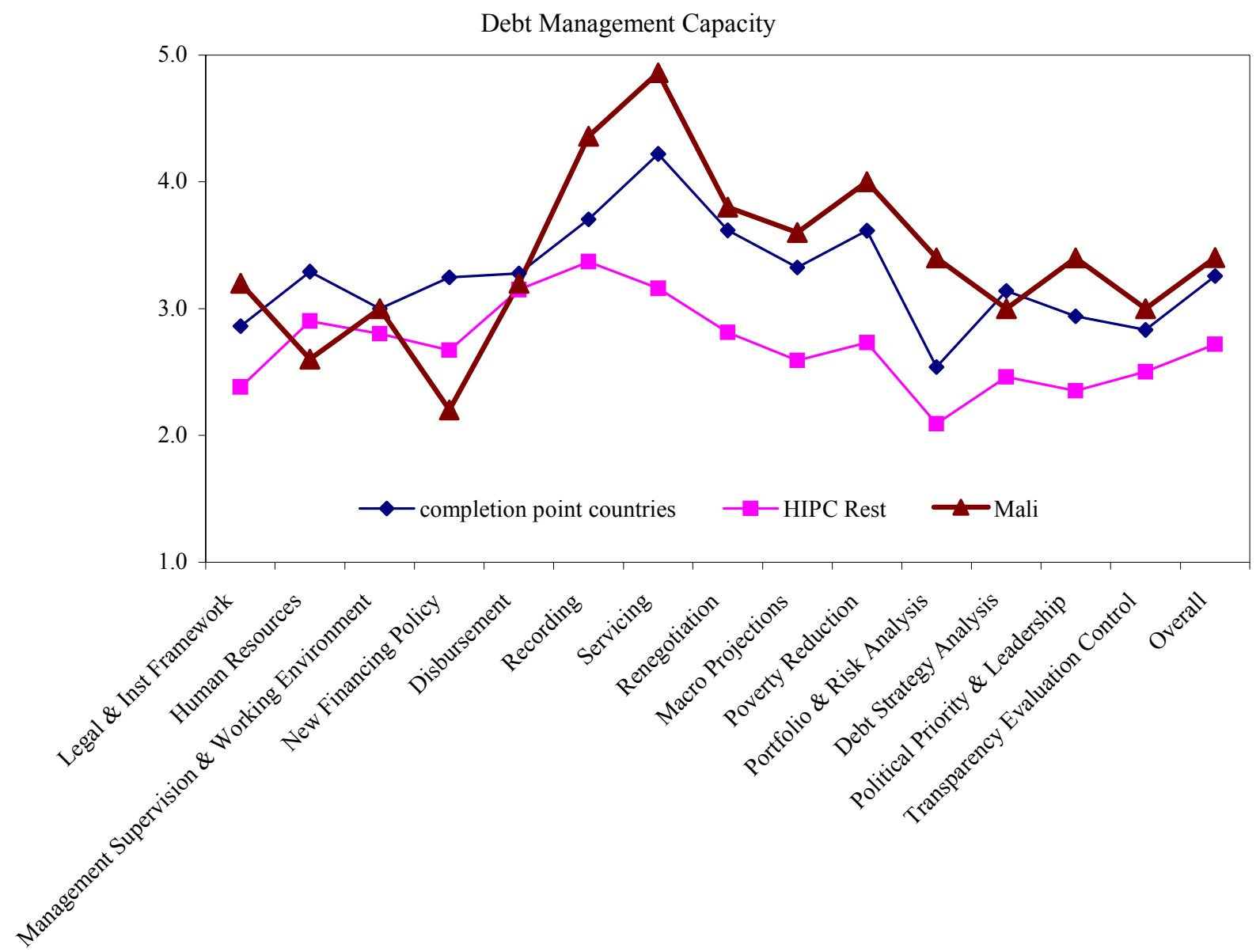

Export Composition

(In percent of total exports)

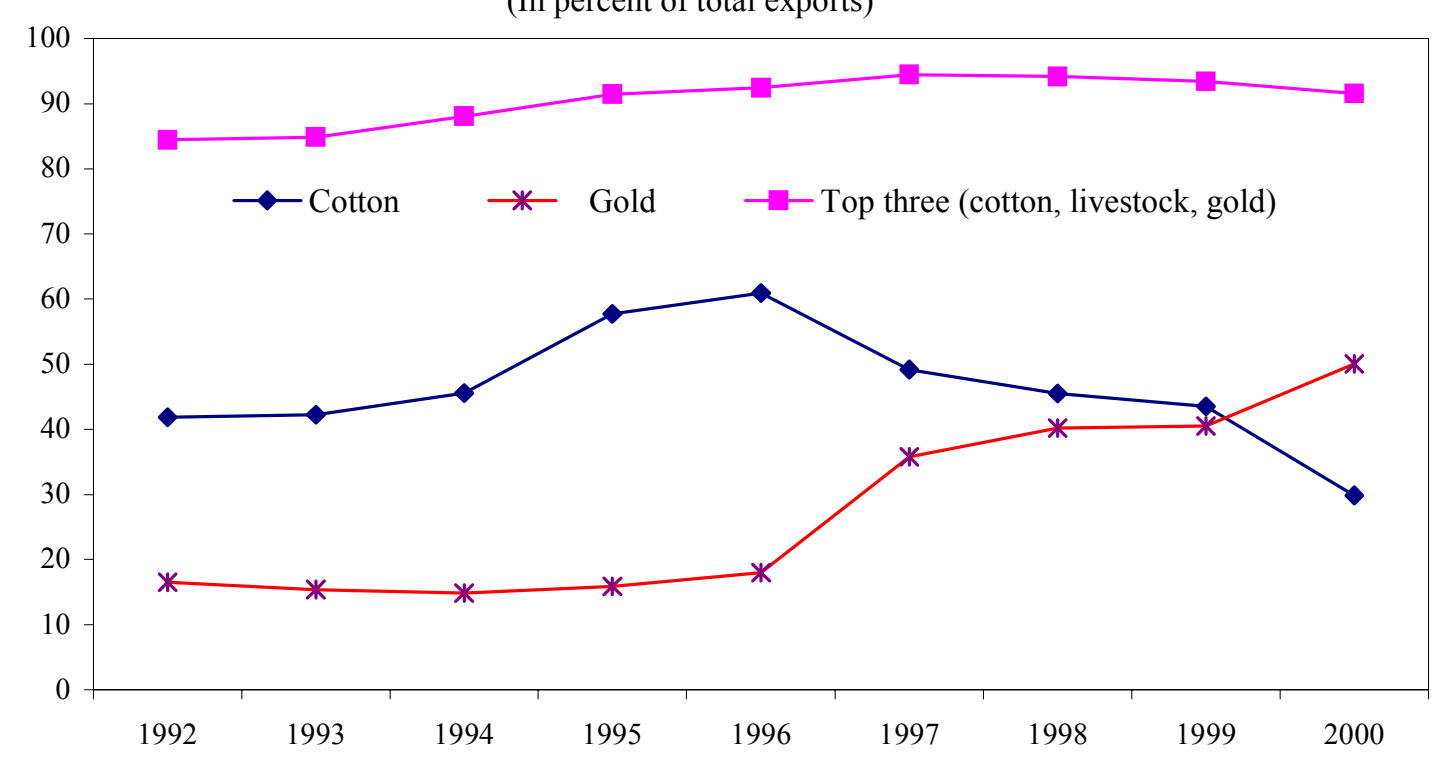


Figure 11: Mauritania

Debt Management Capacity
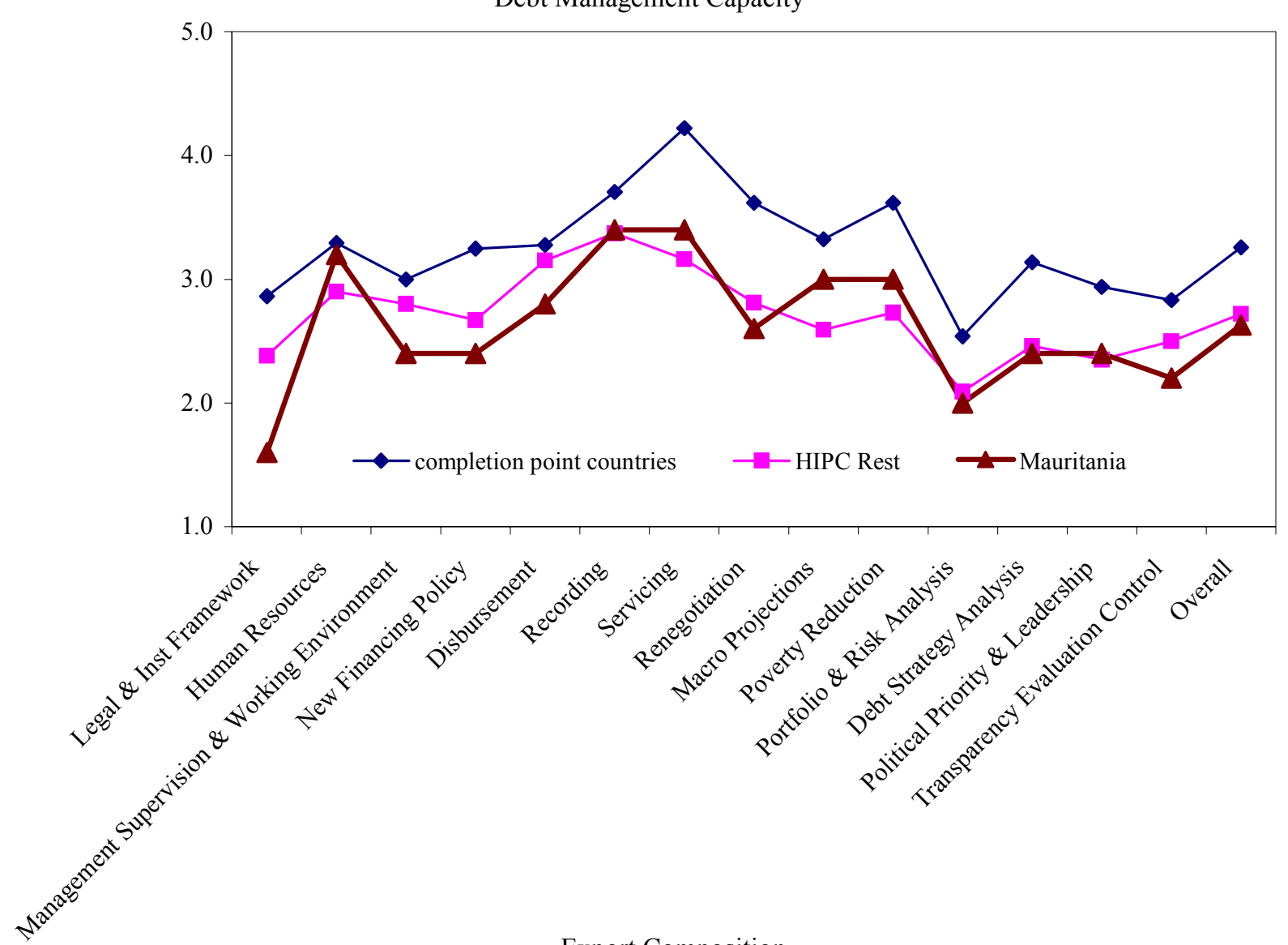

Export Composition

(In percent of total exports)

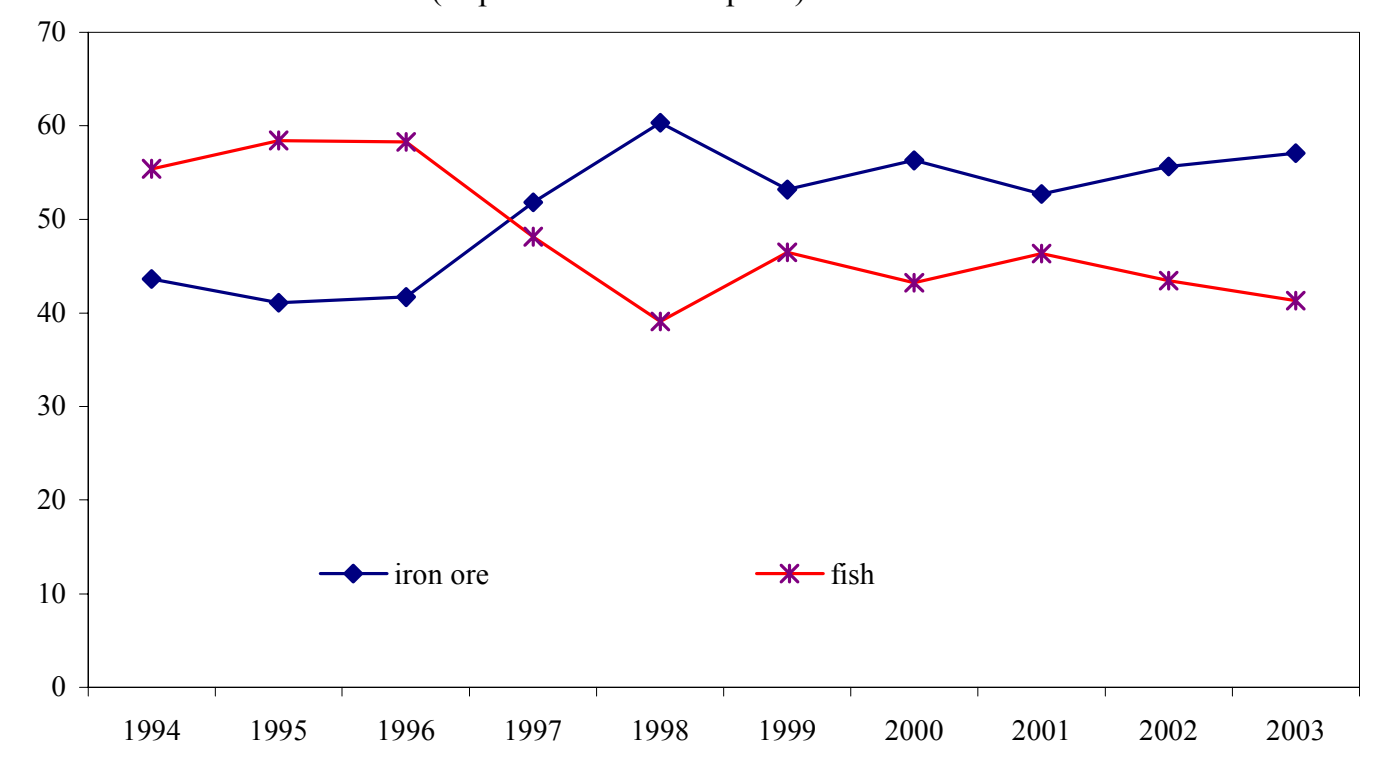


Figure 12: Mozambique

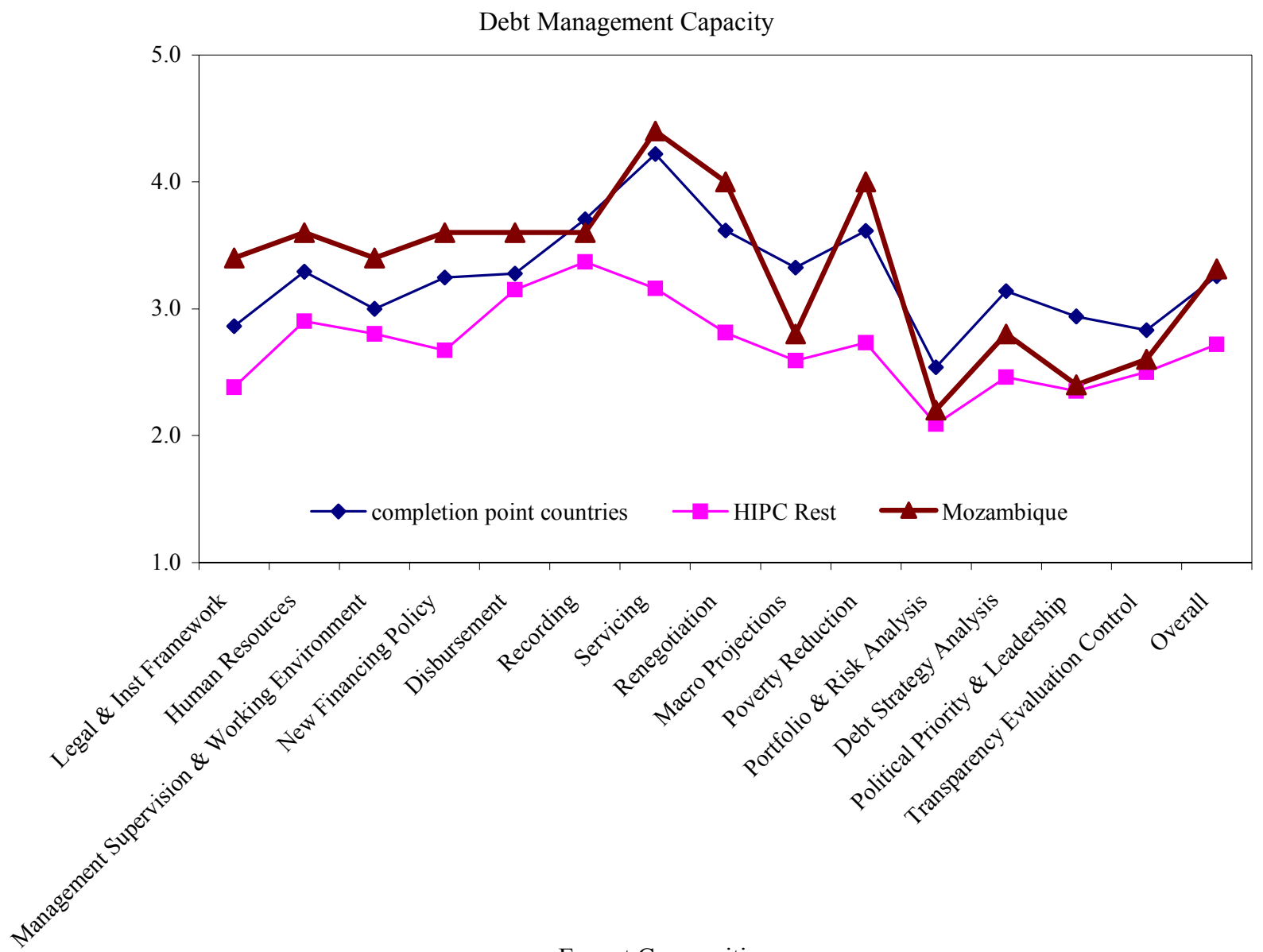

Export Composition

(In percent of total exports)

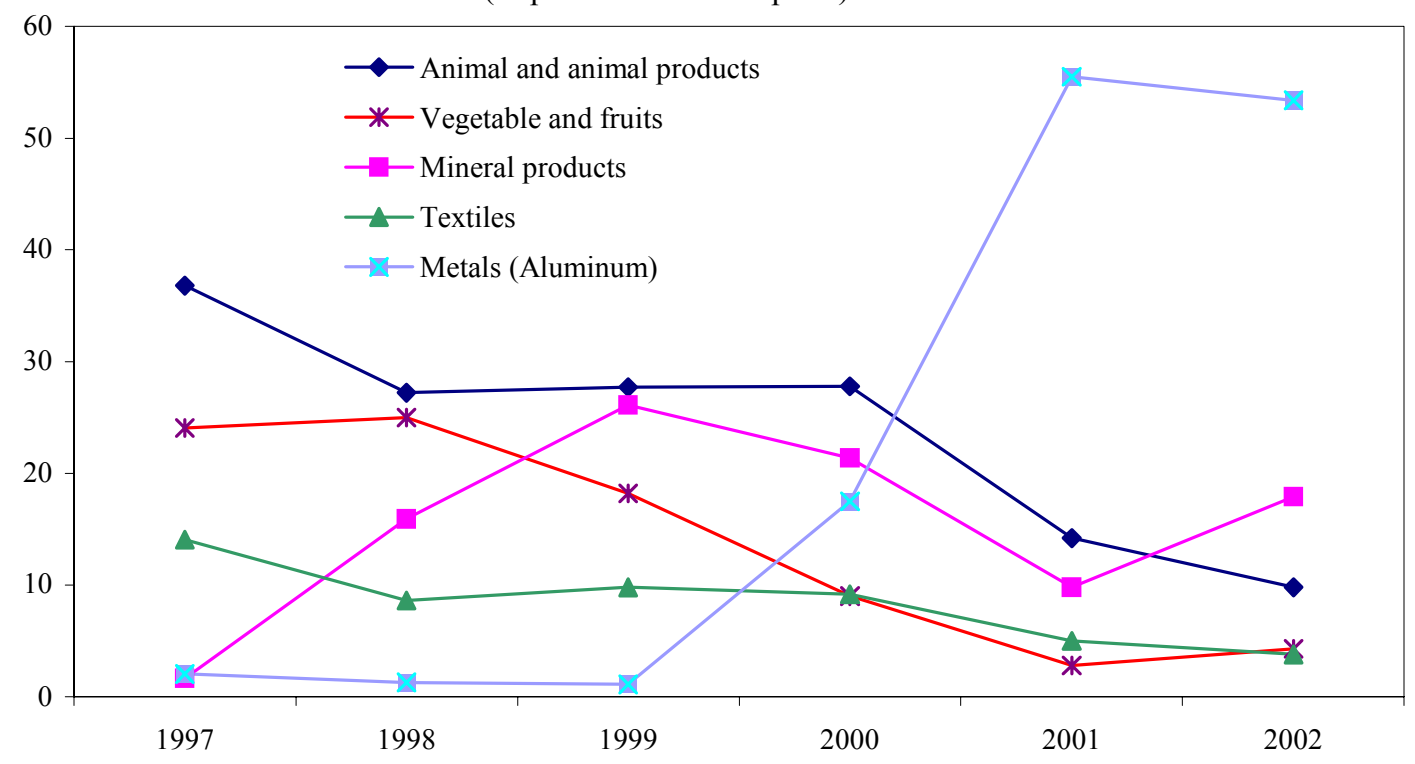


Figure 13: Nicaragua

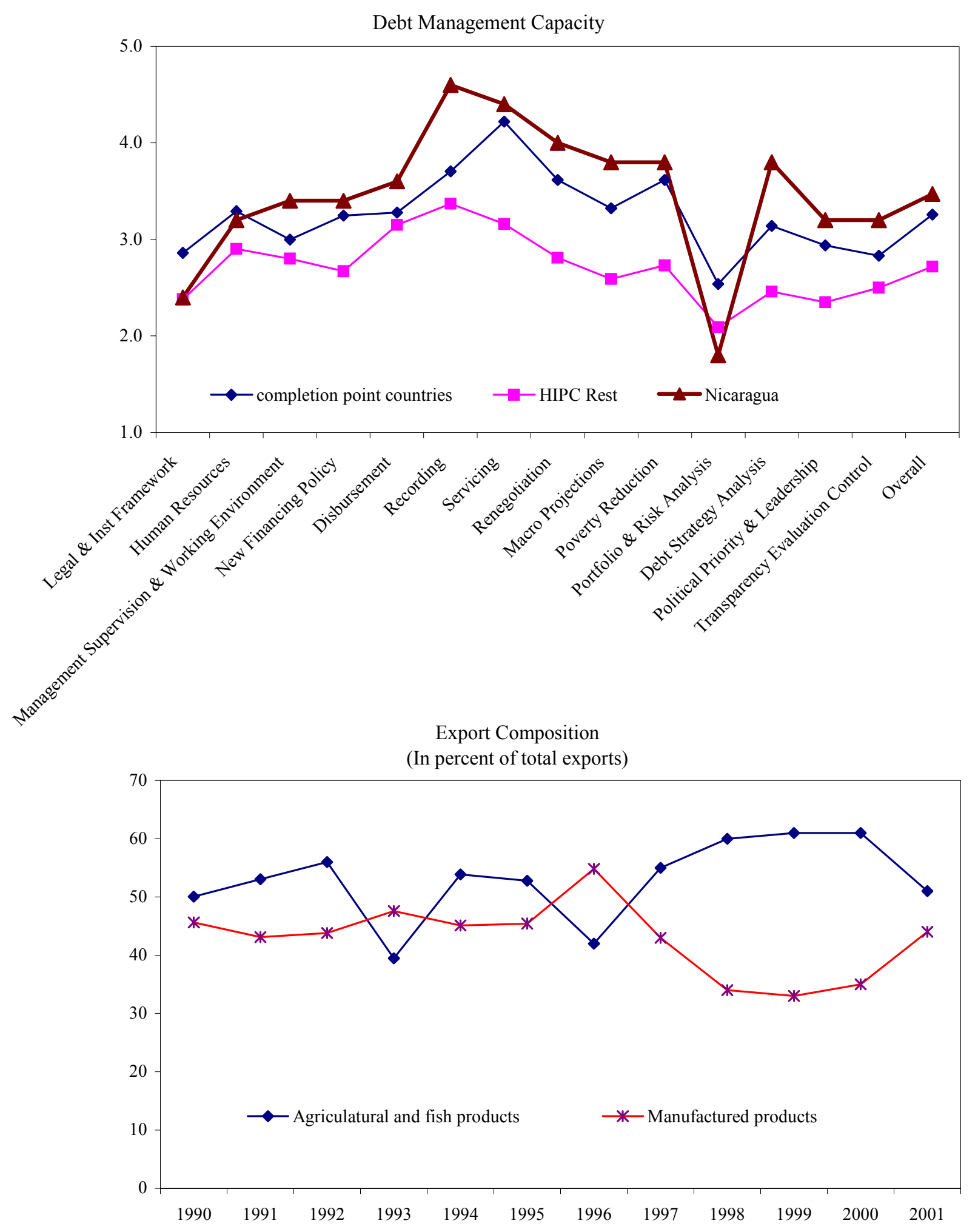


Figure 14: Niger

Debt Management Capacity

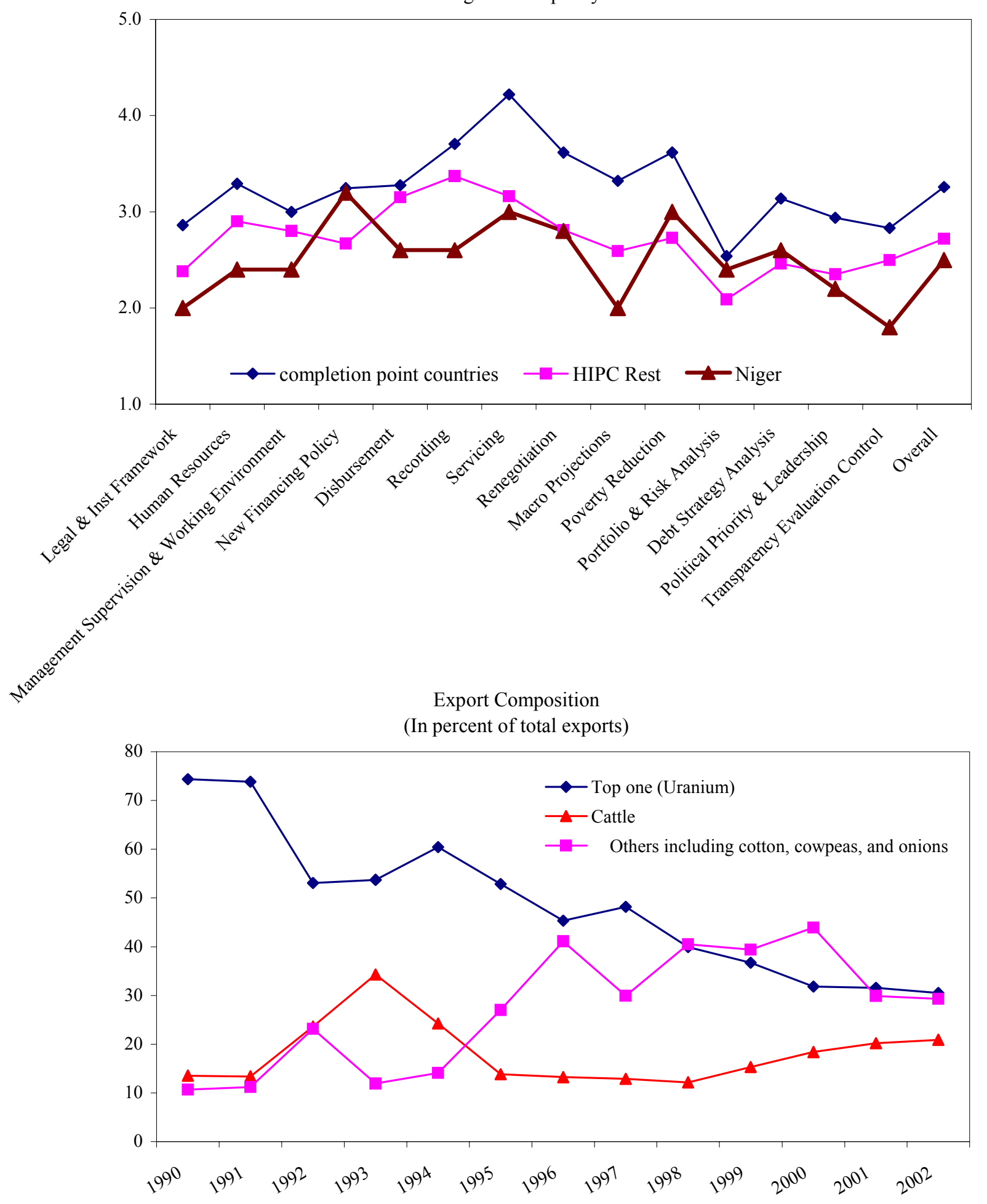


Figure 15: Senegal

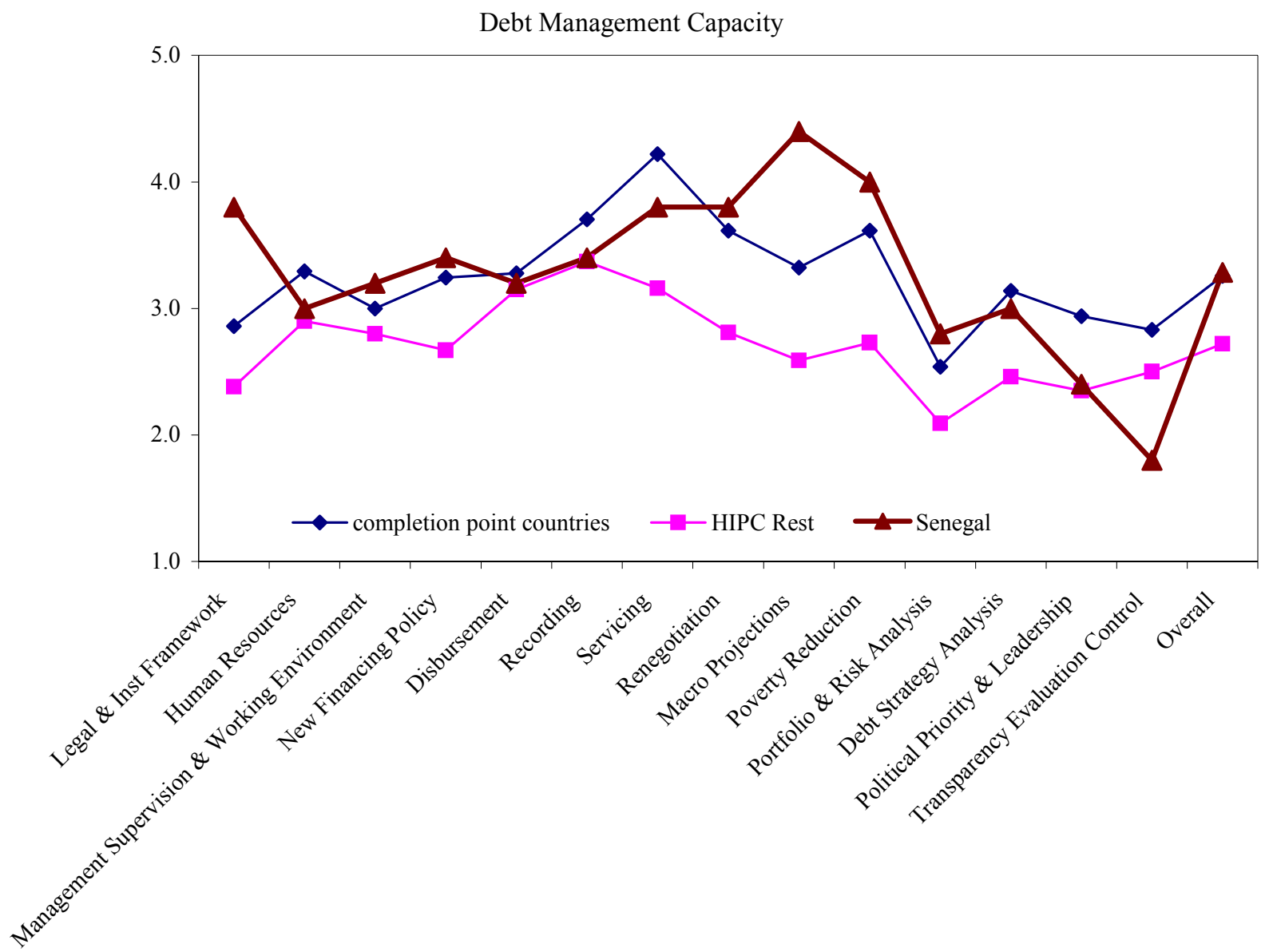

Commodity Export Composition

(In percent of total exports)

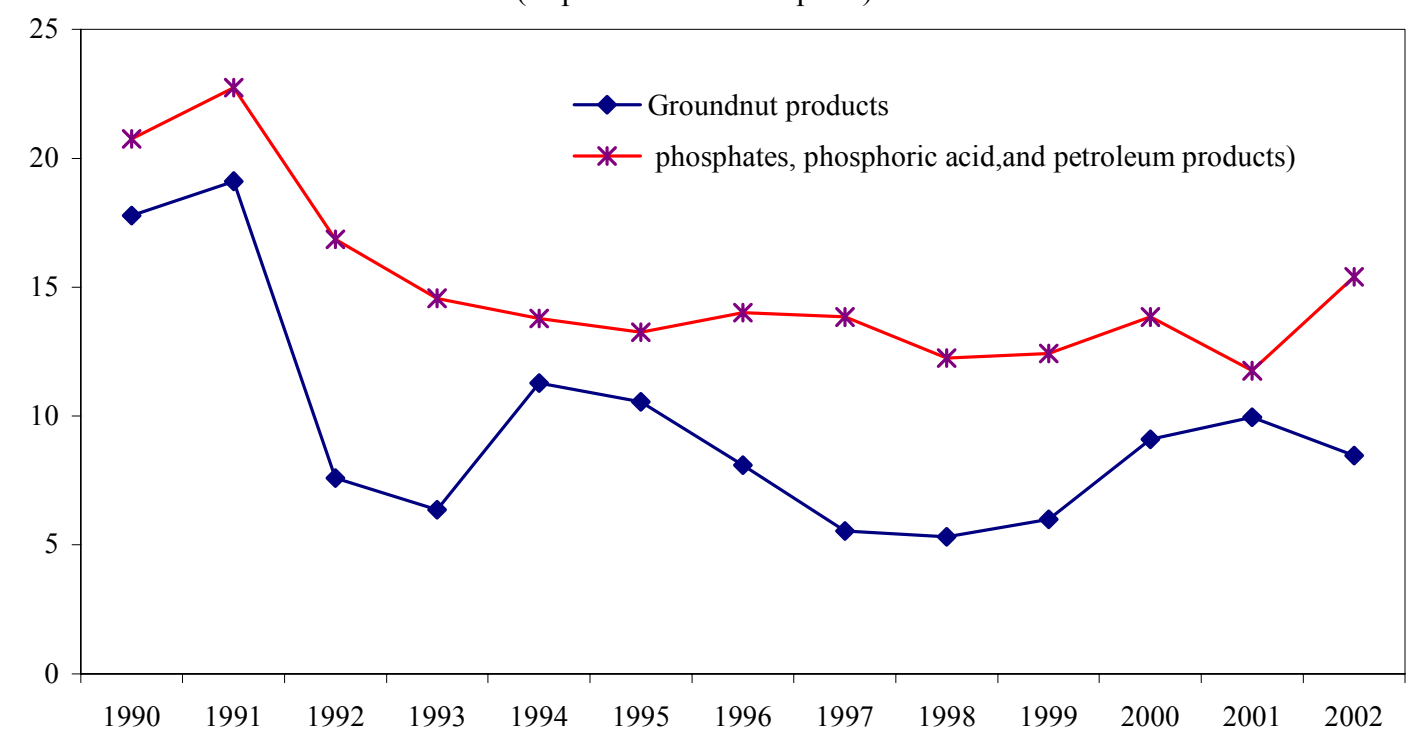


Figure 16: Tanzania

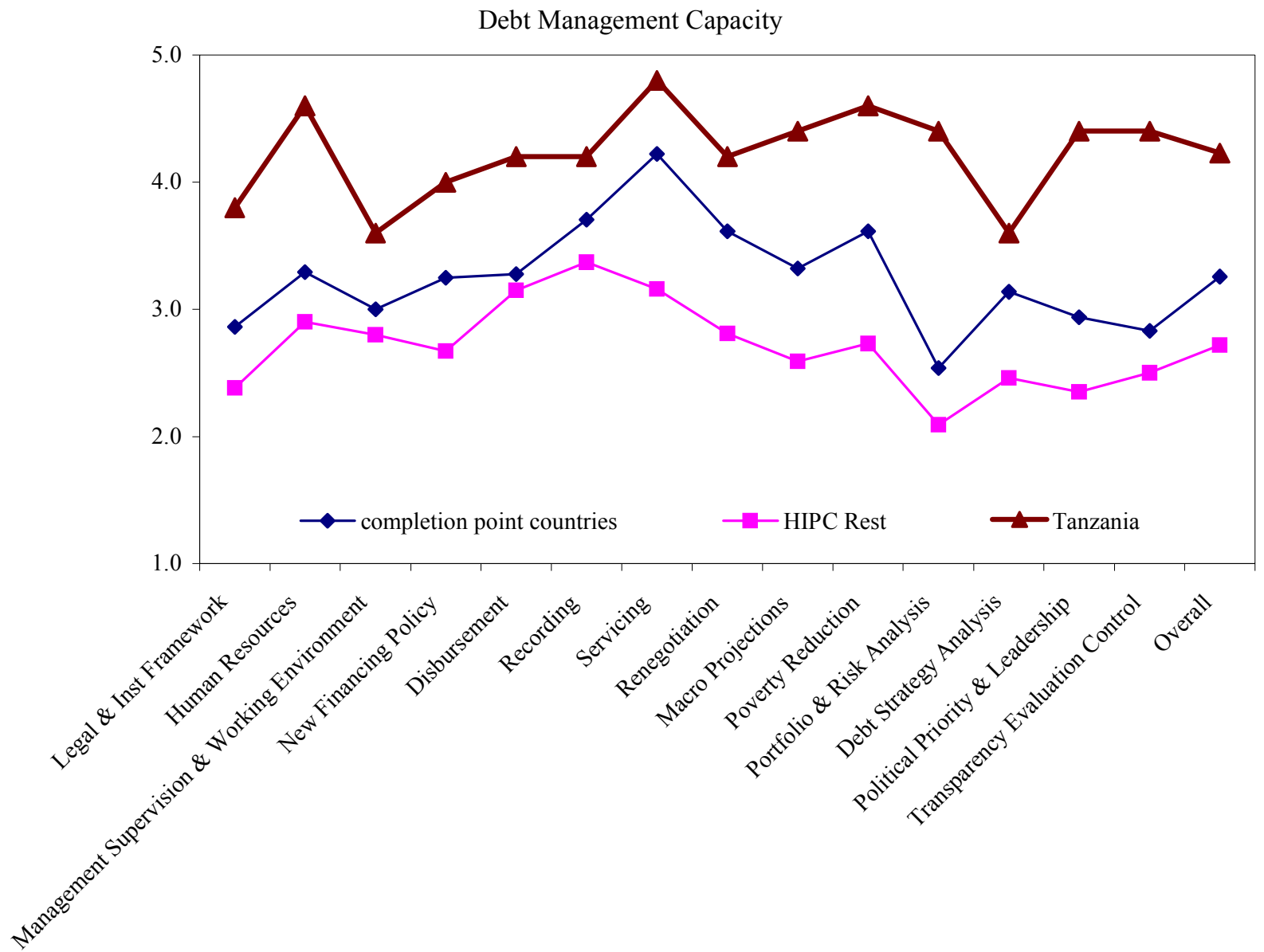

Export Composition

(In percent of total exports)

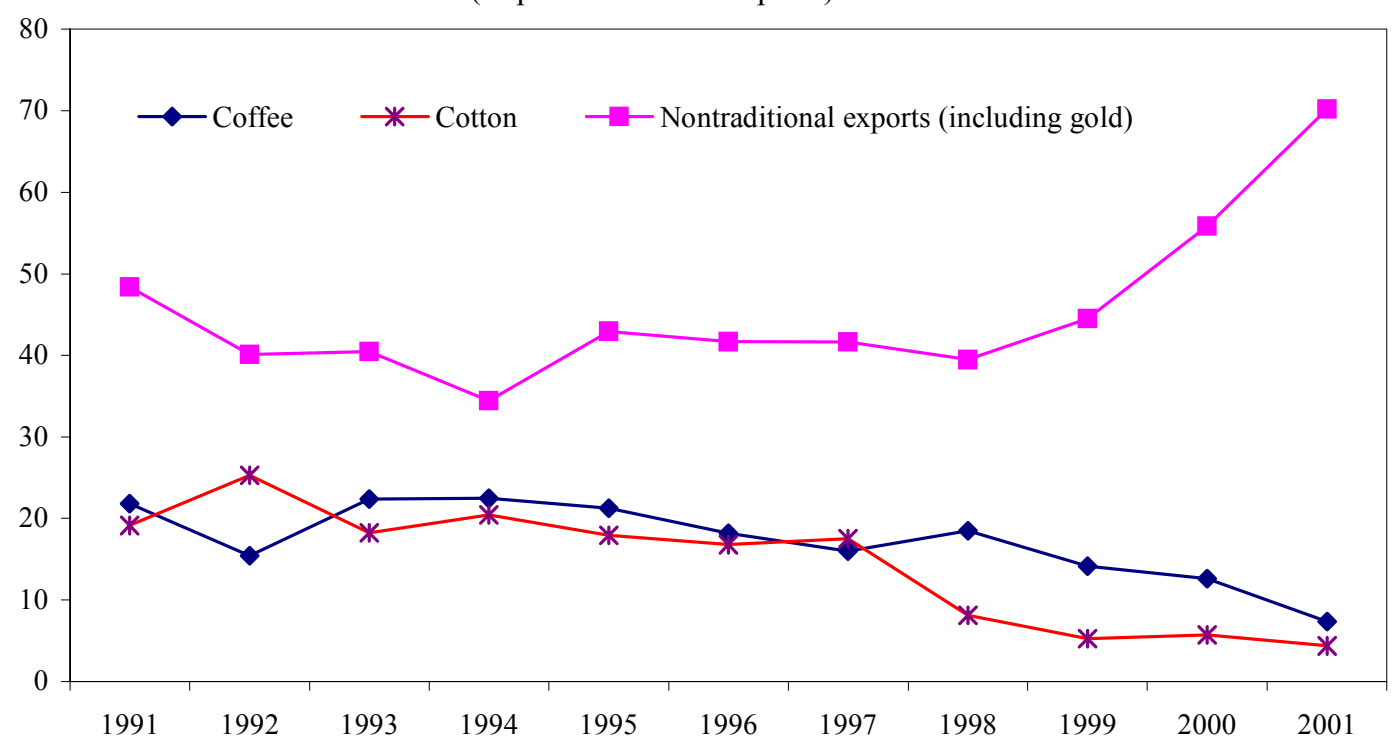


Figure 17: Uganda

Uganda: Debt Management Capacity

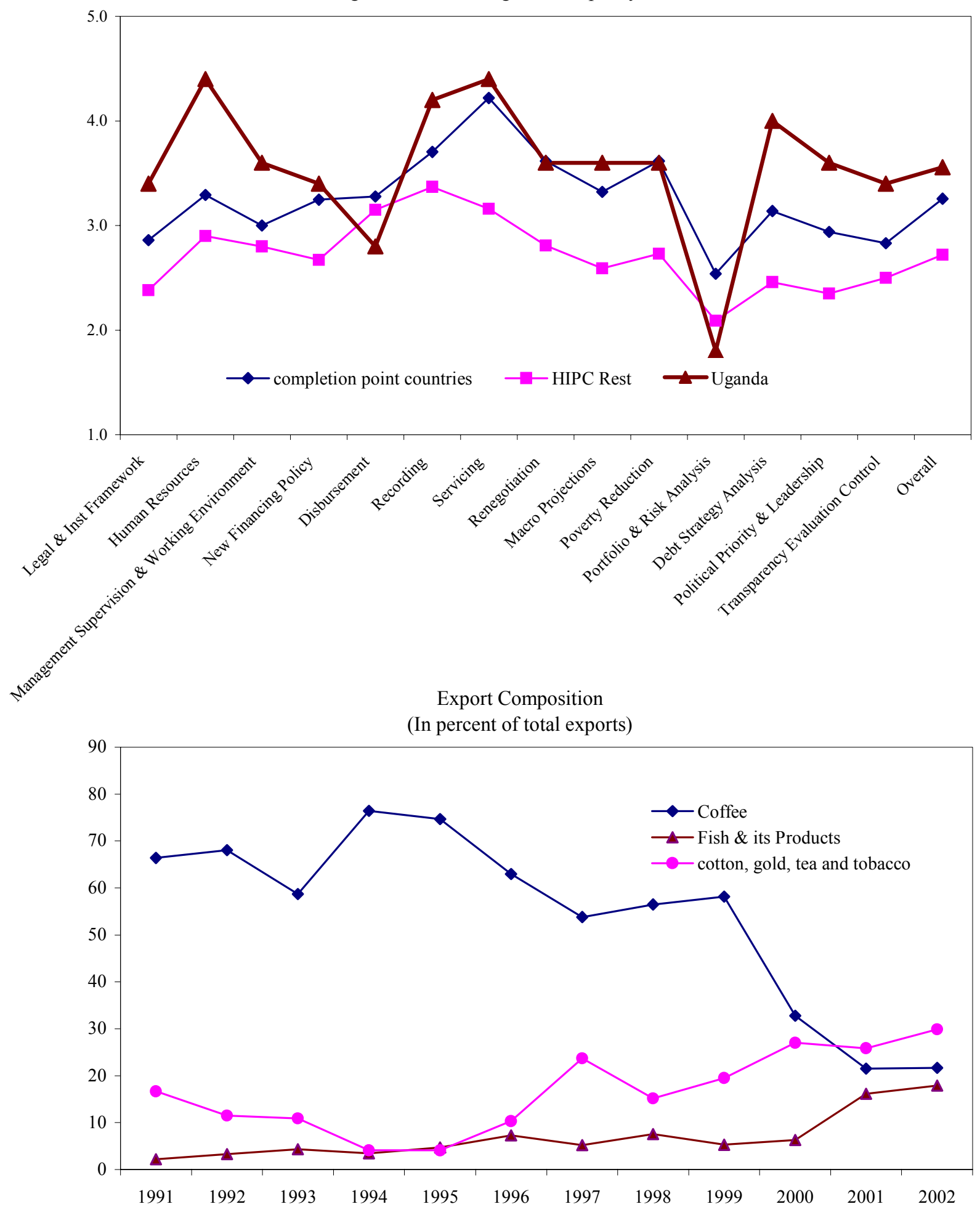




\section{REFERENCES}

Abrego, Lisandro, and Doris Ross, 2001, "Debt Relief Under the HIPC Initiative: Context and Outlook for Debt Sustainability and Resource Flow," IMF Working Paper 01/144 (Washington: International Monetary Fund).

Brooks, Ray, Mariano Cortes, Francesca Fornasari, Benoit Ketchekmen, Ydahlia Metzgen, Robert Powell, Saqib Rizavi, Doris Ross, and Kevin Ross, 1998, "External Debt Histories of Ten Low-Income Countries: Lessons from Their Experience," IMF Working Paper 98/72 (Washington: International Monetary Fund).

Cohen, Daniel, Michele Phamtan, Cristina Rampulla, and Charles Vellutini, 2004, "Beyond the HIPC Initiative" (Paris: Investment Development Consultancy).

International Monetary Fund, 2002a, "External Debt Management in Heavily Indebted Poor Countries (HIPCs)," Washington.

, 2002b, "The Enhanced HIPC Initiative and the Achievement of Long-Term External Debt Sustainability," Washington.

, 2004a, "Debt-Sustainability in Low-Income Countries-Proposal for an Operational Framework and Policy Implications," Washington.

, 2004b, "Enhanced HIPC Initiative-Status of Implementation," Unpublished Draft, Washington.

Kaufmann, Daniel, Aart Kraay, and Massimo Mastruzzi, 2003, "Governance Matters III: Governance Indicators for 1996-2002," World Bank Policy Research Working Paper 3106 (Washington: World Bank).

Pattillo, Catherine, Helene Poirson, and Luca Ricci, 2002, "External Debt and Growth," IMF Working Paper 02/69 (Washington: International Monetary Fund). , 2004, "What Are the Channels Through Which External Debt Affects Growth?" IMF Working Paper 04/15 (Washington: International Monetary Fund).

Powell, Robert, 2003, "Debt Relief, Additionality and Aid Allocation in Low-Income Countries," IMF Working Paper 03/175 (Washington: International Monetary Fund).

World Bank, 2003, “The Heavily Indebted Poor Countries (HIPC) Debt Initiative-An Operations Evaluation Department Review," Washington. 